\title{
Anna Nowicka-Struska*
}

(iD) https://orcid.org/0000-0002-5412-3925

\section{Za murami klasztoru. Historiografia lubelskich karmelitanek bosych}

W 1701 r. kronikarka karmelitanek lubelskich od św. Józefa, opisując drobne i większe sprawy, które wydarzyły się w ich domu od 1698 r., zanotowała m.in.:

Jednak matka przeorysa każda ma przypominać w zgromadzeniu za tych dobrodziejów, o komonijach, dyscyplinach i inszych obligach, bośmy się na to podpisały, co teraz żyjemy, a po nas następujące będą zażywały z tego pożytków, zaczem powinny pamiętać i w modlitwach. Powinne też będą modlić się i za tych dobrodziejów, [...] których tu niektórych może się wspomnieć [...]1.

Po tej zapowiedzi kronikarka wymieniła donatorów klasztoru, którzy na przełomie stuleci wspomagali dom karmelitanek. Uczyniła to, dając jednocześnie wyraz świadomości nieprzerwanej ciągłości losów przeszłych, współczesnych jej i przyszłych pokoleń zakonnic w Lublinie. Po tym akapicie zapis historiograficzny urywa się z nieznanych powodów i nad dziejami karmelitanek lubelskich zapada mrok.

Miejsce to - odzwierciedlające głęboką wiarę sióstr w trwanie konwentu - uznałam za znamienne ze względu na fakt, że cała spuścizna karmelitanek lubelskich uległa rozproszeniu. Wiele przesłanek wskazuje natomiast na to, że w XVII w. tworzyły one środowisko interesujące pod względem piśmienniczym i intelektualnym.

* Dr hab.; Uniwersytet Marii Curie-Skłodowskiej w Lublinie, Instytut Filologii Polskiej, Zakład Badań Teatralnych i Literatury Staropolskiej, Plac Marii Skłodowskiej-Curie 4A, 20-033 Lublin; e-mail: anostruska@gmail.com

1 Kronika klasztoru karmelitanek bosych pw. św. Józefa w Lublinie, oprac. Cz. Gil, Wydawnictwo Flos Carmeli, Poznań 2012, s. 177. 
W Lublinie epoki staropolskiej istniały dwa klasztory karmelitanek bosych, przez które do końca XVIII w. przewinęło się łącznie 180 sióstr². Badanie piśmiennictwa zakonnic w jednorodnej przestrzeni miasta służy przywracaniu pamięci o kilku pokoleniach kobiet, które - choć za wysokim murem - żyły w Lublinie, odkrywaniu ich aktywności intelektualnej, kultury literackiej, obyczajów i zainteresowań, kształtowania obrazu świata.

Zebranie i przebadanie dorobku karmelitanek lubelskich jest interesujące z kilku względów. Lublin był jedynym miastem w XVII w., w którym zostały ufundowane aż dwa żeńskie klasztory karmelitańskie. Taka sytuacja miała miejsce jeszcze w Krakowie, jednak dopiero w kolejnym stuleciu. Interesująca wydaje się odpowiedź na pytanie o poziom intelektualny i dorobek zakonu, jednak nie tyle en bloc, ile w przestrzeni konkretnego miasta, jego specyfiki czy uwarunkowań kulturowych. Ciekawym zagadnieniem badawczym może być również pytanie o relacje między dwoma klasztorami w przestrzeni miasta. Piśmiennictwo kobiet w epoce staropolskiej wciąż otwiera nowe możliwości poznawcze dla literaturoznawców, badaczy zajmujących się geopoetyką, zainteresowanych zagadnieniami pamięci zbiorowej, prywatności, obiegu teksów, tożsamości bohaterek i identyfikacji zbiorowej czy mentalności grupy. Zwłaszcza pozostałe po karmelitankach egodokumenty są dobrym materiałem oglądu naukowego tej wyizolowanej grupy. Mikroskala tego środowiska badawczo pozostaje w obrębie antropologicznej orientacji historycznej ${ }^{3}$.

Istotnym kryterium skłaniającym do sięgnięcia po spuściznę karmelitanek jest proponowana przez Roberta Darntona ${ }^{4}$ inność nie tylko w odniesieniu do współczesnego człowieka, ale także ta zakładana przez twórczynię zakonu i wyraziście podkreślana już w XVII w. Jej znakiem rozpoznawczym, według św. Teresy z Avili, miała być nawiązująca do pierwotnego wzorca monastycznego surowość reguły - realna i symboliczna nieprzekraczalność klauzurowego muru, z którego jednej strony usytuowane było zgromadzenie demonstrujące i kultywujące własne wyizolowanie, $\mathrm{z}$ drugiej zaś jakże ciekawa tej odmienności reszta świata. Zakon w początkach XVII w. w Europie wciąż stanowił awangardę życia monastycznego, a w warunkach polskich od momentu pojawienia się pierwszych zakonników w 1605 r. był zupełnie nowym zjawiskiem ${ }^{5}$. Z jednej strony wspólnota musiała bu-

2 Obliczeniem objęłam zakonnice, które zmarły do 1800 r. Na podstawie: Cz. Gil, Słownik polskich karmelitanek bosych 1612-1914, Wydawnictwo Karmelitów Bosych, Kraków 1999, s. 55-81, 143-160.

3 Zob. S. Roszak, Egodokumenty epoki nowożytnej w perspektywie europejskiej, w: Z dziejów staropolskiego pamiętnikarstwa. Przekroje i zbliżenia, red. P. Borek, Collegium Columbinum, Kraków 2012, s. 15-30.

4 R. Darnton, Wielka masakra kotów i inne epizody francuskiej historii kulturowej, przekł. D. Guzowska, Wydawnictwo Naukowe PWN, Warszawa 2012, s. 18-19.

5 Zob. K. Targosz, Piórem zakonnicy. Kronikarki w Polsce XVII wieku o swoich zakonach i swoich czasach, Wydawnictwo „Czuwajmy”, Kraków 2002, s. 81. 
dować struktury organizacyjne, pozyskiwać fundatorów i donatorów, z drugiej zaś zakonnicy i mniszki od początku swojego funkcjonowania w kraju starali się kreować wizerunek Karmelu tak pod kątem sobie współczesnych, jak i przyszłych pokoleń zakonnych, dla których mieli stać się częścią tradycji, pionierami i wzorcami.

Większość dorobku piśmienniczego polskich zakonnic od św. Teresy została zebrana w Bibliotece i Archiwum Karmelitanek Bosych w Krakowie ${ }^{6}$. Tamtejsze zasoby powstały w wyniku zgromadzenia w mieście, po tzw. kasatach józefińskich, ostatnich sióstr z likwidowanych klasztorów. Zakonnice przywoziły ze sobą archiwalia klasztorne $\mathrm{z}$ różnych domów $\mathrm{z}$ terenu całej Rzeczypospolitej. Jednak w niewielkiej liczbie trafiły tam zasoby lwowskie i lubelskie. Nie wiadomo, co stało się z rękopisami, dokumentami, biblioteką i całym dorobkiem piśmienniczym obydwu klasztorów z Lublina, których spuścizna uległa niemal całkowitemu rozproszeniu $^{8}$. Scalenie informacji na temat zasobu źródłowego rękopisów karmelitanek lubelskich obydwu konwentów, identyfikacja nowo odkrytych tekstów związanych ze środowiskiem lubelskim oraz prezentacja najważniejszych dla niego postaci kobiecych stanowią cel szerszego projektu obejmującego opis wszystkich form piśmienniczych uprawianych w jednej przestrzeni przez uczestniczki wspólnoty. Metoda ta może okazać się pożyteczna również ze względu na fakt, że piśmiennictwo karmelitanek w różnorodnych badaniach traktowane było całościowo bez uwzględniania konkretnego środowiska i pochodzenia tekstów ${ }^{9}$. Artykuł ten stanowi, po pierwsze, próbę określenia najważniejszych cech części dorobku zakonnic - historiografii karmelitanek bosych, a po drugie, próbę wskazania autorek tekstów, które w dotychczasowych badaniach były uznawane za nierozpoznane.

Karmelitanki bose pojawiły się w Lublinie w 1624 r., dając początek klasztorowi pw. św. Józefa. Był to drugi w Polsce konwent należący do tego zakonu, który powstał 12 lat po krakowskiej fundacji św. Marcina. Pierwszymi zakonnicami, które

6 Dalej: BKB.

7 W ten sposób w Krakowie znalazły się dokumenty: rękopisy klasztoru warszawskiego, część rękopisów wileńskich, pierwszego uznawanego za macierzysty w Rzeczypospolitej klasztoru krakowskiego pw. św. Marcina oraz jedynego nieskasowanego klasztoru na Wesołej. Chociaż do Krakowa nie zostały przeniesione karmelitanki poznańskie, to w zbiorach znajdują się również rękopisy wielkopolskie. Zasoby karmelitanek wileńskich są również w klasztorze na Łobzowie w Krakowie. Na Wesołej w XIX w. znalazła się część konwentu wileńskiego i cały warszawski. Zob. J.B. Wanat, Katalog rękopisów Biblioteki Karmelitanek Bosych na Wesołej, mps dostępny na miejscu, s. I-IV. Siostry poznańskie, przeniesiono po1823 r. do klasztoru cysterek w Owińskach. Zob. Cz. Gil, Słownik polskich karmelitanek..., s. 187. Lwowianki po kasacie z końca XVIII w. rozproszyły się po kilku klasztorach. Zob. B. Wanat, Zakon Karmelitów Bosych w Polsce. Klasztory karmelitów i karmelitanek bosych 1605-1975, Wydawnictwo OO. Karmelitów Bosych, Kraków 1979, s. 647.

8 J.B. Wanat, Zakon Karmelitów Bosych w Polsce..., s. 625, 655-655.

9 H. Popławska, Kultura literacka karmelitanek bosych (XVII-XVIII wiek), Wydawnictwo Uniwersytetu Gdańskiego, Gdańsk 2006. 
przybyły do Lublina, były: Anna od Jezusa Stobieńska, Eufrazja od św. Jacka Piaseczyńska, Dorota od Najświętszej Marii Panny Decjuszówna, i nowicjuszka, Teresa od Józefa Maryi Ligęzina ${ }^{10}$. Wszystkie one stanowiły w późniejszych latach ścisły zarząd klasztoru i należały do czołówki polskiego Karmelu. Klasztor ten pozyskał w kolejnych latach przychylność Zofii i Jana Mikołaja Daniłowiczów - stali się najważniejszymi donatorami fundacji, osobiście związanymi zwłaszcza z Anną od Jezusa. Ich głębokie relacje z karmelitankami oraz osobiste zaangażowanie religijne sprawiły, że postanowili ufundować kolejny klasztor w Lublinie, pw. Niepokalanego Poczęcia Najświętszej Marii Panny. Jego założycielkami były Teresa Barbara od Najświętszego Sakramentu Zadzikowa, Maria Magdalena od Zbawiciela Żaboklicka i Beata Kolumba od Jezusa Drzewicka. Oba konwenty zostały połączone w 1807 r., kiedy siostry józefatki po pożarze lubelskiego klasztoru karmelitów bosych przeniesiono do klasztoru poczętek, a ich dom oddano zakonnikom" Klasztor pw. Niepokalanego Poczęcia Najświętszej Marii Panny został ostatecznie skasowany w 1819 r. Budynki klasztorne konwentu św. Józefa przejęte zostały przez karmelitów bosych, a nieruchomości konwentu Niepokalanego Poczęcia Najświętszej Marii Panny w 1826 r. przeszły pod zarząd Sióstr Miłosierdzia św. Wincentego à Paulo. Można przypuszczać, że zasoby materialne, archiwalia i książki józefatek przeniesiono początkowo do klasztoru poczętek, nie wiadomo jednak, w jakich okolicznościach do tego doszło i co się stało z rękopisami, dokumentami, biblioteką i całością dorobku obydwu klasztorów po 1826 r..$^{12}$

Wyjaśnić należy kategorię „lubelskości”. Karmelitanki rzadko zmieniały konwenty, większość z nich całe życie, od momentu nowicjatu do śmierci, spędzała w jednym domu. Jedynymi okolicznościami przemieszczania się bosaczek było udanie się na nową fundację, ewentualnie ucieczka całego zgromadzenia w czasie wojny lub epidemii. Formalnie macierzystym domem bosaczki pozostawał ten, w którym składała ona śluby, na zawsze zachowywała prawo powrotu do niego. W sytuacji badania kultury literackiej środowiska lubelskiego przyjęto zasadę, że na jego jakość miały wpływ wszystkie siostry, które znalazły się w lubelskich klasztorach. To doprecyzowanie jest istotne zwłaszcza wobec kilku postaci, na przykład Anny Stobieńskiej, która była profeską krakowską, jednak większość swojego zakonnego życia związała z Lublinem, Teresy Barbary od Najświętszego Sakramentu, profeski od św. Józefa, założycielki konwentu Niepokalanego Poczęcia i późniejszej fundatorki klasztoru poznańskiego, w którym spędziła ostatnie lata życia. Podobna sytuacja wiąże się z osobą Teresy Barbary od Najświętszego Sakramentu i jej towarzyszkami, które wyjechały do Wielkopolski w 1665 r., również na ich

\footnotetext{
10 Karmelitanki po wstąpieniu do klasztoru przyjmowały predykaty. $\mathrm{W}$ artykule podawane są obok siebie imiona zakonne i nazwiska świeckie.

11 J. B. Wanat, Zakon Karmelitów Bosych w Polsce..., s. 625.

12 Tamże, s. 655-655.
} 
ukształtowanie miało wpływ przede wszystkim środowisko lubelskiego Karmelu. O ile kwestia „lubelskości” nie jest pierwszorzędna w badaniu historiografii klasztornej, w której przypadku dziejopisarstwo bezdyskusyjnie przynależy do konkretnego konwentu, o tyle kategoria ta staje się kłopotliwa przy analizowaniu innych form wypowiedzi piśmienniczych, np. modlitewników czy sylwicznych zbiorów duchowościowych, które zmieniały miejsce wraz z peregrynującą autorką czy właścicielką.

Jakiego rodzaju źródła pisane pozostały po lubelskich karmelitankach? Istnieje pewna liczba dokumentów znajdujących się w archiwach polskich dotyczących przede wszystkim spraw majątkowych ${ }^{13}$. Te rękopisy pozostają jednak poza obszarem moich zainteresowań badawczych.

Drugą grupę dokumentów dotyczących karmelitanek lubelskich stanowią materiały „urzędowe”, związane z funkcjonowaniem klasztorów. Zachowała się księga wizytacji klasztoru karmelitanek bosych pw. Niepokalanego Poczęcia Najświętszej Marii Panny z lat 1650-1824 $4^{14}$. Rękopis ten prowadzony był z obydwu stron kodeksu i gromadził świadectwa wizytacji generalnych oraz prowincjalnych. Dokument mieszczący się na jednej stronie rękopisu obejmował ocenę stanu duchowego i zachowania reguły zakonnej. W części poświęconej wizytacjom generalnym zamieszczony był podwójny przekaz, na stronie verso znajdował się zapis łaciński podobnej oceny, na stronie recto mniszki wpisywały polskie tłumaczenie

13 Wypisy z akt grodzkich i miejskich dotyczące spraw majątkowych Karmelitanek Bosych (józefatek) w Lublinie 1650-1782, Archiwum Państwowe Lublin (dalej: APL) 35/110/16; Ugoda między Klasztorem Karmelitanek Bosych (józefatek) a Lejzorem Abrahamowiczem w sprawie pożyczki pieniężnej 1728 r., sygn. 35/110/16; Sprawy majątkowe Karmelitanek - Poczętek w Lublinie 16321674, APL sygn. 35/.110/117; [Akta zgromadzenia PP karmelitanek bosych w Lublinie], Archiwum Główne Akt Dawnych sygn. 1/190/o; Karmelitanki lubelskie, 1/354/o Archiwum Warszawskie Radziwiłtów; Jan Kazimierz uwalnia od wszelkich podatków dwa ogrody kupione dla Karmelitanek - poczętek w Lublinie, APL sygn. 35/110/117; Sumariusze różnych spraw sądowych dot. majątku nieruchomego Karmelitanek Początek w Lublinie, APL sygn. 35/110/117; Akta interesu PP[anien]: Karmelitanek Bosych Lubelskich pod tytułem Św. Józefa we wsi Wielkim, AGAD Archiwum Gospodarcze Wilanowskie sygn. 1/342/o; Procesy Adama Lubowieckiego i Urszuli z Krasickich, właścicieli Rudna z karmelitankami bosemi lubelskimi i z plebanem rudniańskim, Archiwum. Państwowe. Przemyśl Archiwum Zamku Leskiego Krasickich sygn. 56/158/o; [Akta dotyczące funduszu religijnego klasztorów karmelitów bosych i karmelitanek w Lublinie, którego spłatę przejęły władze austriackie], Archiwum Główne Akt Dawnych sygn. 1/178/o Rząd Centralny Wojskowy Tymczasowy Obojga Galicji z 1809 r.; Zofia hrabianka z Tenczyna, żona Mikołaja Daniłowicza, podskarbiego Wielkiego Koronnego daje dwór z placem Początkom, dawniej należący do Broniewskich, APL sygn. 35/110/17 Klasztor Karmelitanek Bosych („poczętek”) w Lublinie; Akta klasztorów rzymskokatolickich woj. lubelskiego - zbiór szczątków zespołów, APL sygn. 35/110/0617.

14 Liber visitationum generalium / Księga wizytacyj prowincyjalnych, PAU PAN, Kraków, rkps 2337 II. 
dokumentu. Karmelitanki innych konwentów prowadziły księgi przyjęć i profesji, księgi zmarłych, nie łączyły ich, tak jak to miało miejsce w innych zakonach, $\mathrm{z}$ pozostałymi formami piśmiennictwa, np. z kronikami. Żaden $\mathrm{z}$ takich zbiorów pochodzących od lubelskich bosaczek nie zachował się.

Oprócz wspomnianych archiwaliów piśmiennictwo karmelitanek lubelskich obejmuje: omówione dalej certaminy ${ }^{15}$ i kroniki ${ }^{16}$, żywoty zakonnic ${ }^{17}$, sylwiczne zbiory konstytutywnych dla formacji zakonnej tekstów duchowościowych ${ }^{18}$, modlitewniki osobiste ${ }^{19}$, jedną kantyczkę ${ }^{20}$ i niewielki zbiór listów. Wiedzę o środowisku intelektualnym karmelitanek wzbogacają fragmentaryczne informacje proweniencyjne o posiadanym przez nie księgozbiorze ${ }^{21}$. Jednym $\mathrm{z}$ najcenniejszych źródeł do badania kultury literackiej i środowiska intelektualnego lubelskich bosaczek są pochodzące z klasztoru Niepokalanego Poczęcia zakonne adaptacje zbioru Pia desideria Hermana Hugona ${ }^{22}$.

Niniejszy artykuł stanowi część szerszej pracy, której celem jest przebadanie całości piśmiennictwa jednego zakonnego środowiska kobiecego w spójnej przestrzeni miasta. Pierwszym etapem tak zakrojonej próbie monografii jest charakterystyka dziejopisarstwa lubelskich bosaczek, których kroniki były, obok przede wszystkim hagiografii klasztornej, jedną z form historiograficznych. W dotychczasowych badaniach kronikarstwo zakonne budziło zainteresowanie przede wszystkim jako od-

15 W Bibliotece Karmelitanek Bosych w Krakowie zespoły certaminów, przechowywane są w archiwum. BKB Archiwum, sygn. 44, 46.

16 Kronika klasztoru karmelitanek bosych; rkps Archiwum Prowincji Karmelitów Bosych, AP 104; BKB rkps 255; Księgi, w których są krótko opisane żywoty, BKB rkps 253.

17 O żywotopisarstwie zakonnic lubelskich zob. A. Nowicka-Struska, Opowieści szeptane .O bliskości kobiet na podstawie żywotopisarstwa lubelskich karmelitanek bosych, w: Sława z dowcipu sama wiecznie stoi... Prace ofiarowane Pani Profesor Alinie Nowickiej-Jeżowej z okazji pięćdziesięciolecia pracy naukowej, red. M. Hanusiewicz-Lavallee, W. Pawlak, Lublin 2018, s. 213-229.

18 Są to między innymi kodeksy w: Bibliotece Poznańskiego Towarzystwa Przyjaciół Nauk, rkps 130; Archiwum Prowincji Karmelitów Bosych, rkps 246.

19 Archiwum Prowincji Karmelitów Bosych, rkps AP 246; Biblioteka Wyższego Seminarium Diecezjalnego w Lublinie, rkps 455, rkps 457.

20 Biblioteka PAN PAU w Krakowie, rkps 1731.

21 Dane proweniencyjne zebrała mi Pani Elżbieta Bylinowa z Biblioteki Uniwersytetu Warszawskiego, podobnie jak pięć krótkich listów karmelitanek klasztoru Niepokalanego Poczęcia NMP. Za przekazane mi informacje serdecznie dziękuję.

22 Pragnienia dusze pobożnej, rkps Lwowskiej Narodowej Naukowej Biblioteki Ukrainy im. W. Stefanyka, sygn. CTI118348. Zob. J. Gwioździk, Kultura pisma i książki w żeńskich klasztorach dawnej Rzeczypospolitej XVI-XVIII wieku, Wydawnictwo Uniwersytetu Śląskiego, Katowice 2015, s. 228; A Nowicka-Struska, „Strzały serdeczne z Pisma świętego i ojców świętych zrobione, a od dusze nabożnej ku niebu wypuszczone”. Siedemnastowieczna adaptacja „Pia desideria” Hermana Hugona z rękopisu lubelskich karmelitanek bosych klasztoru Niepokalanego Poczęcia Najświętszej Marii Panny, „Terminus” 2016, t. 18, nr 2 (39), s. 131-159. 
miana historiografii, świadectwo aktywności umysłowej kobiet i dowód ich aspiracji intelektualnych, jak też źródło analizy kategorii prywatności kobiecej w XVII i XVIII w. ${ }^{23}$ Aktywności tej warto przyjrzeć się również pod kątem struktur literackich kronik, cech egodokumentalistyki czy nieodkrytego dotąd autorstwa.

Przeszłość obydwu konwentów jest personalnie rozpoznana dzięki zachowanym certaminom - tekstom sytuującym się na pograniczu archiwaliów administracyjnych i epistolografii. Warto w tym miejscu wspomnieć o tej formie piśmiennictwa zakonnego. Były to listy wysyłane przed świętem Podwyższenia Krzyża (14 IX) do klasztoru św. Marcina w Krakowie w imieniu wszystkich zakonnic zamieszkujących poszczególne konwenty. Dokumenty te miały też stanowić zachętę do wysiłku duchowego ${ }^{24}$. Za każdym razem pod listem podpisywały się wszystkie zakonnice z danego klasztoru. O zwyczaju tym wspominają kroniki zakonne ${ }^{25}$. Każdorazowe wskazanie w nich mieszkanek klasztorów umożliwiło pełne odtworzenie tej grupy w XVII i XVIII w ${ }^{26}$. Wśród zasobów pochodzących z całej Rzeczypospolitej są też obszerne zbiory certaminów lubelskich - od około połowy XVII w. do okresu kasat józefińskich. Zachowane listy z klasztoru św. Józefa pochodzą z lat 1648-1786²7. Certaminy z lubelskiego klasztoru karmelitanek bosych pw. Niepokalanego Poczęcia Najświętszej Marii Panny, choć klasztor funkcjonował od 1649/1650 r., obejmują listy z lat 1655-1806 z bardzo niewielkimi ubytkami ${ }^{28}$.

Certaminy nie przekraczały objętości jednej strony tekstu. Przy niektórych podpisach pojawiały się określenia precyzujące pełnioną przez zakonnicę funkcję.

23 K. Targosz, dz. cyt., s. 7-14. M. Borkowska, Panny siostry w świecie sarmackim, Wydawnictwo Naukowe PWN, Warszawa 2002; taż, Życie codzienne polskich klasztorów żeńskich w XVIIXVIII wieku, Państwowy Instytut Wydawniczy, Warszawa 1996; A. Nowicka-Struska, Dom i świat. Prywatność domu klasztornego w świetle kroniki karmelitanek bosych klasztoru św. Józefa w Lublinie i tekstów regulujących ich życie w Karmelu, w: Sarmackie theatrum, t. 7: W kręgu rodziny i prywatności, red. M Jarczykowa, R. Ryba, Wydawnictwo Uniwersytetu Śląskiego, Katowice 2014, s. 187-208; taż, Duchowość i piśmiennictwo karmelitańskie w Polsce XVII i XVIII wieku, w: Drogi duchowe katolicyzmu polskiego XVII wieku. Kultura Pierwszej Rzeczypospolitej w dialogu z Europq. Hermeneutyka wartości, t. 7, red. A Nowicka-Jeżowa, Wydawnictwo Uniwersytetu Warszawskiego, Warszawa 2016, s. 344-393; J. Partyka, Żona wyćwiczona. Kobieta pisząca w kulturze XVI i XVII wieku, Wydawnictwo IBL PAN, Warszawa 2004; A. Nowicka-Struska, Listy w kręgu kulturowym karmelitanek bosych w XVII i XVIII wieku. Ze studiów nad rękopisami z Biblioteki Karmelitanek Bosych, w: Epistolografia w dawnej Rzeczypospolitej, t. 5: Stulecia XVI-XIX. Nowa perspektywa historycznoliteracka, red. M. Olma, P. Borek, Collegium Columbinum, Kraków 2015, s. 193-214.

24 Zob. A. Nowicka-Struska, Listy w kręgu kulturowym karmelitanek...

25 Klasztory karmelitanek bosych w Polsce, na Litwie i Rusi. Ich początek i tułactwo w czasie rozruchów wojennych $w$ XVII wieku. Rzecz osnuta na kronikach klasztornych. Kraków. Klasztor św. Marcina, wyd. R. Kalinowski, druk "Czasu”, Kraków 1904, s. 69.

26 Zob. Cz. Gil, Słownik polskich karmelitanek.... dz. cyt.

27 Certamina lubelskie z klasztoru św. Józefa, Archiwum BKB, sygn. 44.

28 Certamina klasztoru Niepokalanego Poczęcia, Archiwum BKB , sygn. 46. 
Obowiązek sformułowania listu spoczywał na przeoryszy. Chronologiczne zestawienie tych dokumentów pokazuje niezmienność charakteru pisma, świadczące o sprawowaniu urzędu przez jedną osobę niekiedy przez wiele lat. Teksty te miały wszystkie formalne cechy pism epistolograficznych. W dwustuletniej historii staropolskiego Karmelu zakonnice dosyć rzadko pozostawiały swoje „ślady na piasku" - nieczęsto podpisywały kopiowane, komponowane przez siebie czy samodzielnie tworzone teksty, rękopisy i zbiory. Certaminy są dokumentami, w których zakonnice ujawniały swoją tożsamość. Mimo że w księgach profesji czy nowicjuszek lub w księgach zmarlych odnotowywane były ich dane, pochodzenie, daty wstąpienia, ślubów oraz wejścia do nowicjatu, to jednak rokroczne potwierdzanie przez nie swego istnienia należy uznać za ważne.

Listy te, posiadające konieczne elementy wypowiedzi epistolograficznej, miały niezmienną strukturę formalną, na którą składały się: nagłówek „Jezus + Maria” i określenie adresata, a następnie we właściwej treści listu zakonnice podawały trzy cnoty (np. milczenie, czystość serca i pokora), które w specjalny sposób miały być przez nie praktykowane w najbliższym roku. Zobowiązania były też graficznie wyodrębnione jako kolejne punkty tekstu ${ }^{29}$. Etymologia słowa certamen wskazywała na semantyczny krąg, potyczki, walki i zawodów. Certaminy były zatem rodzajem „wyzwania duchowego wobec przeciwnika zewnętrznego - świata, wewnętrznego czy też rodzajem wewnątrzzakonnej rywalizacji duchowej"”.

Niekiedy teksty te przyjmowały kształt małych traktatów ascetycznych. W listach pochodzących z okresów kształtowania się domu klasztornego, pionierskiej żarliwości duchowej, zwłaszcza w pierwszych latach działania klasztoru Niepokalanego Poczęcia Najświętszej Marii Panny, odnaleźć można predylekcję do głęboko zmetaforyzowanego wyrażania myśli. Ich wyrazistą cechą jest intertekstualnośćs1. Listy te uwidaczniają między innymi doskonałą znajomość wśród karmelitanek pism Jana od Krzyża. Niektóre z certaminów lubelskich z połowy XVII w. uwite są z wątków sanhuańskich i ich kluczowych inspiracji - metaforyki oblubień-

29 Niekiedy zakonnice nie tylko składały duchowe zobowiązania i prosiły o modlitwę za ich szczęśliwą realizację, ale też kierowały inne duchowe prośby pod adresem zakonnic klasztoru św. Marcina w Krakowie. I tak np. w 1687 r. zwróciły się o modlitwę za duszę „namilszej siostry i dobrodziejki, siostry Pauli Maryi, aby jako najprędzej twarzą w twarz patrzała na Boga swego". Ta wyjątkowa prośba dotyczyła Heleny Tekli Lubomirskiej. Córka Jerzego Ossolińskiego i wdowa po Aleksandrze Lubomirskim przez długie lata była rezydentką klasztoru warszawskiego i jego fundatorką. Do lubelskich poczętek wstąpiła w 1681 r., zaś habit i pełne śluby zakonne mogła przyjąć dopiero na łożu śmierci 30 maja 1687 r. Zob. Klasztory karmelitanek bosych w Polsce, na Litwie i Rusi. Ich początek i tułactwo w czasie rozruchów wojennych w XVII wieku. Rzecz osnuta na kronikach klasztornych. Warszawa, druk „Czasu” Kraków 1902, s. 91-97.

30 Zob. Cz. Gil, Słownik polskich karmelitanek..., s. 6; A. Nowicka-Struska, Listy w kręgu kulturowym karmelitanek..., s. 204-208.

31 A. Nowicka-Struska, Listy w kręgu kulturowym karmelitanek..., s. 207. 
czej Pieśni nad pieśniami. Pośród listów lubelskich zwięzłością myśli i walorami literackimi oraz subtelnym przejawem wyzyskania tekstów przynależących do ukształtowanego już wówczas kanonu lektur karmelitańskich wyróżniają się listy z lat 1661-1665, pochodzące z klasztoru Niepokalanego Poczęcia Najświętszej Marii Panny. Ich autorką była najprawdopodobniej Maria Magdalena od Zbawiciela Żaboklicka, ówczesna przeorysza ${ }^{32}$, postać siedemnastowiecznego piśmiennictwa kobiecego, o której pamięć warto przywrócić.

Najważniejszymi źródłami wiedzy o lubelskich karmelitankach były kroniki klasztoru pod wezwaniem św. Józefa oraz fragmenty kroniki klasztoru Niepokalanego Poczęcia Najświętszej Marii Panny. Kroniki klasztorne były w XVII i XVIII w. rozpowszechnionym $\mathrm{w}$ zakonach rodzajem piśmiennictwa i wiele zgromadzeń praktykowało tę formę domowej historiografii, w żaden sposób nieskodyfikowanej i niepodlegającej kliszy formalnej, tak jak w przypadku certaminów ${ }^{33}$. Zazwyczaj kroniki zakonne miały charakter pośredni pomiędzy prowadzonymi księgami zmarłych, księgami obłóczyn, profesji, metryką ${ }^{34}$ a regularnie prowadzoną narracją, przedstawiającą w porządku chronologicznym wydarzenia z życia grupy. Kroniki domowe spisywali również karmelici ${ }^{35}$. Karmelitańskie księgi dziejów konwentualnych przechowywane były razem z najważniejszymi dokumentami domowymi w specjalnych skrzyniach zamykanych na trzy zamki ${ }^{36}$. O ile, jak wynika

32 Zob. Cz. Gil, Stownik polskich karmelitanek..., s. 60.

33 Zob. K. Targosz, dz. cyt.; J. Gwioździk, Piśmiennictwo pragmatyczne w klasztorach żeńskich w XVII-XVIII wieku: zarys problematyki, w: Piśmiennictwo pragmatyczne w Polsce do końca XVIII wieku na tle powszechnym, red. J. Gancewski, A. Wałkówski, Pracownia Wydawnicza EISet, Olsztyn 2006, s. 43-59.

34 K. Targosz, dz. cyt.; A. Szylar, Kronika bernardynek lubelskich 1618-1885, Towarzystwo Naukowe Katolickiego Uniwersytetu Lubelskiego Jana Pawła II Lublin 2010; W. Szołdrski, Kronika benedyktynek chełmińskich, „Miesięcznik Diecezji Chełmińskiej” 1937, s. 509-529; M. Borkowska, Kronika pierwsza (metryka), w: K. Górski, M. Borkowska, Historiografia zakonna a wzorce świętości w XVII wieku, Warszawa 1984, s. 278-328; s. 329-335; s. 336-342; s. 342-360; Kronika fundacyjna klasztoru mniszek zakonu kaznodziejskiego na Gródku w Krakowie (1620-1639), wstęp i oprac. A. Markiewicz, Kraków 2007; Metryka brygidek lubelskich, oprac. J. R. Marczewski, Lublin 2011; M. Borkowska, Życie codzienne...; Cz. Gil, Życie codzienne karmelitanek bosych w Polsce w XVII i XVIII wieku, Wydawnictwo OO. Karmelitów Bosych Kraków 1997; A. Nowicka-Struska, Dom i świat..., s. 187-208; H. Pawłowska, Zainteresowanie życiem publicznym w kronikach grodzieńskich z XVII-XVIII wieku - zarys problematyki, „Barok” 2011, nr 1, s. 83-93.

35 Np. kronika karmelitów poznańskich, warszawskich, które doczekały się edycji: Kronika poznańskich Karmelitów Bosych, oprac. P Neumann, Poznań 2001; Kronika klasztoru karmelitów bosych w Warszawie, wstęp, przekł., oprac. Cz. Gil, „Karmelitańskie Studia i Materiały Historyczne" 2009, t. 2, s. 143-377.

36 Instructiones Fratrum Discalceatorum Romae 1693, s. 127-130. Cyt. za: Cz. Gil, Wstęp, w: Kronika klasztoru karmelitów bosych w Warszawie, s. 147. 
z kronik, karmelici powoływali klasztornych kronikarzy, którzy ujawniali swoje imiona, o tyle nie wiadomo, na jakiej zasadzie i kto piastował tę funkcję w klasztorach żeńskich ${ }^{37}$. Wiemy, że siedem na osiem istniejących w epoce staropolskiej domów zakonnych karmelitanek bosych prowadziło kroniki, ale tożsamości kronikarek często nie jesteśmy w stanie poznać. Większość ich tekstów wydał Rafał Kalinowski ${ }^{38}$. Planował on również edycję kroniki lubelskiej sióstr od św. Józefa. Nie zostało to urzeczywistnione z powodów finansowych, a do edycji tekstu przyczynił się dopiero Czesław Gil ${ }^{39}$. Jedyna zachowana kopia rękopiśmienna zapisków pochodzi z początków $\mathrm{XX}$ w.40

Prowadzenie zapisków historiograficznych nie wynikało $\mathrm{z}$ reguły zakonnej, lecz raczej podyktowane było naśladownictwem działalności św. Teresy - założycieli i autorki dziejów swoich fundacji ${ }^{41}$. Wydaje się, że powyższy argument pisania jako naśladowania Świętej założycielki nie wyczerpuje jednak tematu. Drugim, jak sądzę, istotnym imperatywem spisywania kronik, zwłaszcza jej początkowych części, była świadomość wagi dzieła - nowego klasztoru w obrębie nowego zakonu w Rzeczypospolitej. Obydwa, według założeń, miały trwać długo, karmelitanki zaś żywiły głębokie przeświadczenie, że kładą dopiero fundamenty tego dzieła. Kolejne konwenty powstające w XVII stuleciu powtarzały praktykowane w starszych klasztorach obyczaje. Nie wiadomo według jakich zasad zlecano w poszczególnych konwentach pisanie kroniki konkretnym siostrom. Znane są imiona niektórych z nich. Wiemy, że pierwszą autorką kroniki krakowskiej od św. Marcina była najprawdopodobniej Magdalena od Krzyża Hipolitówna; drugiej fundacji

37 Karmelici bosi pozostawili zapiski kronikarskie, wiadomo o prowadzonej kronice klasztoru w Wiśniczu (z lat 1624-1719), w Warszawie (z lat 1634-1718), zachowany jest fragment kroniki z Wiśniowca (1733-1742), kopia kroniki z Ostrej Bramy (1624-1790), najobszerniejsza zachowana kronika pochodzi z Poznania (1618-1756).

38 Klasztory karmelitanek bosych w Polsce, na Litwie i Rusi... Kraków, dz. cyt. w tomie również kronika klasztoru św. Teresy i św. Jana od Krzyża, s. 239-290; Klasztory karmelitanek bosych w Polsce, na Litwie i Rusi. .... Warszawa, dz. cyt.; Klasztory karmelitanek bosych w Polsce, na Litwie i Rusi. Ich początek i tułactwo w czasie rozruchów wojennych w XVII wieku. Rzecz osnuta na kronikach klasztornych. Wilno, druk "Czasu”, Kraków 1900; Klasztory Karmelitanek bosych w Polsce, na Litwie i Rusi: ich początek, rozwój i tułactwo w czasie rozruchów wojennych w XVII wieku: rzecz osnuta na kronikach klasztornych. Lwów - Warszawa, wyd. R. Kalinowski, druk „Czasu”, Kraków 1901.

39 Kronika klasztoru karmelitanek bosych....

40 Oryginał kroniki józefatek znajdował się w XIX w. w zbiorach Konstantego Przeździeckiego. Dla Rafała Kalinowskiego sporządzony został ok. 1896 r. jej odpis, który stał się podstawą współczesnej edycji, jest to rkps APKB AP 104. Oryginał kroniki spłonął wraz resztą zbiorów Przeździeckiego w 1944 r. w Warszawie. Nie zachowała się cała kronika klasztoru Niepokalanego Poczęcia Najświętszej Marii Panny (zob. Cz. Gil, Wstęp, w: Kronika klasztoru karmelitanek bosych, s. 7).

41 K. Targosz, dz. cyt., s. 9-10. 
krakowskiej - Anna Józefa od Pana Jezusa Rupniewska; wileńskiej - Katarzyna od Chrystusa Pana Tyszkiewiczówna; lwowskiej (początkowy okres) - Teresa od Jezusa Marchocka; poznańskiej - Eufrazja od Zwiastownia Najświętszej Marii Panny Pajewska; warszawskiej (tzw. „drugiej”) - Eufrozyna od Pana Jezusa Jordanówna ${ }^{42}$. Jak dotąd nie zostały wskazane imiona autorek kronik lubelskich.

Narrację o dziejach każdej fundacji karmelitańskiej zazwyczaj rozpoczynała uroczysta część, w której opisane były okoliczności założenia konwentu. Ten inicjalny fragment przechodził płynnie w kronikę prowadzoną przez kolejne lata. W lubelskiej ta początkowa część nosi tytuł Krótkie opisanie założenia klasztoru panieńskiego Zakonu Karmelitańskiego. Roku Pańskiego MDCXXIV 1625 pierwszego dnia listopada $w$ dzień Wszystkich Świętych. Struktura kroniki, pozycja narratora oraz zamknięcie rozdziału szóstego wskazują na to, że ten wstępny segment tworzyło sześć pierwszych rozdziałów odnoszących się do wydarzeń z lat 16211624. Po nich nastąpiło przejście do opowieści o życiu bosaczek w kolejnych latach. Kroniki karmelitanek bosych, na co dzień spoczywające bezpiecznie w skrzyni, częściowo były wprowadzane w wewnętrzny obieg. W początkach XVIII w. kopia tej części kroniki lubelskiej, jak również dziejów klasztoru Niepokalanego Poczęcia Najświętszej Marii Panny, została włączona do kodeksu grupującego podobne opisy fundacyjne wszystkich klasztorów w Rzeczypospolitej ${ }^{43}$. Jest to o tyle ważne, że wobec nieistniejącego obecnie rękopisu kroniki józefatek i nieznanych losów zapisków poczętek rękopis ten jest jedynym pochodzącym z epoki zapisem dziejów obydwu konwentów. Kodeks sporządziła wielokrotna przeorysza krakusek Cecylia Teresa od Ofiarowania Najświętszej Marii Panny (Anna Petronela Zacherlanka) ${ }^{44}$. Zawiera on opisy fundacji klasztorów w porządku ich powstawania Kraków, Lublin św. Józefa, Wilno, Lwów, Lublin Niepokalanego Poczęcia, Warszawa, Poznań, spisanych przez kilka sióstr. Rękopis zapewne powstał przed 1725 rokiem ${ }^{45}$. Pomię-

42 K. Targosz, dz. cyt., s. 290-291.

43 BKB rkps 255: Księga fundacyj klasztorów karmelitanek bosych Prowincyjej Polskiej Ducha Świętego.

44 „Sporządzenie” w tym przypadku nie oznacza, że został przepisany przez jedną zakonnicę. Cechy pisma wskazują, że autorka wspominanej adnotacji przepisała Opisanie fundacyi... krakowskiego konwentu św. Marcina. Możliwe zatem, że Cecylia Teresa była autorką ozdobnej karty tytułowej zbioru lub pomysłodawczynią całości. Zob. A. Nowicka-Struska, Listy w kręgu kulturowym karmelitanek, s. 213.

45 Nie została do niego dodana relacja z fundacji klasztoru św. Teresy od Jezusa i św. Jana od Krzyża na Wesołej w Krakowie, powstałego w 1725 r. Zacherlanka była związana z tą fundacją i na rzecz nowego klasztoru przygotowała jakieś rękopiśmienne kopie, o czym informuje kronika tego konwentu: Klasztory karmelitanek... Kraków, s. 272: „Druga siostra Cecylia Teresa od Ofiarowania Panny Przenajświętszej także pracowała z afektem Pana Boga, przysłużyć się osobliwie księgi klasztorne sporządzając, Regułę i inne potrzebne przepisując egzercycyje i inne duchowne ćwiczenia nasze zakonne dając odprawować, instrukcyje, dyscypliczki, obyczaje 
dzy odpisem kroniki józefatek z początku XX w., będącym podstawą współczesnego wydania, a tą kopią, zatytułowaną Krótkie opisanie założenia 2-go klasztoru panieńskiego, istnieją rozbieżności niedostrzeżone dotąd przez badaczy i wydawcę. Jako siódmy w rękopisie krakowskim dołączony został odnoszący się do początku lat trzydziestych XVII w., a pochodzący z dalszej części kroniki rozdział osiemnasty: O budowaniu nowego klasztoru i wprowadzeniu nas do niego przez różne osoby. Prawdopodobnie na potrzeby tej pracy lubelska kopistka skomponowała na nowo Krótkie opisanie, dołączając rozdział z późniejszej historii konwentu, dotyczący ostatecznego osiedlenia się sióstr w murowanym klasztorze.

W rękopisie tym, jak już wspomniano, znalazła się także wstępna część kroniki lubelskiego konwentu Niepokalanego Poczęcia Najświętszej Marii Panny ${ }^{46}$, co jest istotne ze względu na fakt, że tekst pełnej kroniki się nie zachował. Wydawca dziejów józefatek powątpiewał nawet, czy tzw. poczętki w ogóle prowadziły zapiski ${ }^{47}$. Wydaje się jednak, że ze względu na wyraźną w zakonie skłonność do kultywowania zwyczajów klasztornych nie należy wątpić w pielęgnowanie tej tradycji przez drugi konwent lubelski. Oprócz tego w całościowej kopii tekstu józefatek, $\mathrm{w}$ rozdziale trzydziestym znalazły się luźne fragmenty odnoszące się do dziejów karmelitanek od Niepokalanego Poczęcia, prawdopodobnie pochodzące z ich zaginionej kroniki ${ }^{48}$. Ponadto spisany przez Marię Magdalenę od Zbawiciela Żaboklicką, żywot matki Teresy Barbary od Najświętszego Sakramentu Zadzikowej ${ }^{49}$, w niektórych partiach tekstu, zwłaszcza odnoszących się do lat ok. 1649-166o, ujawnia cechy dziejopisarstwa klasztornego, o czym będzie jeszcze mowa.

Kronika lubelskich józefatek obejmuje okres od 1624 do 1701 r. Podzielona została na pięćdziesiąt rozdziałów, przy czym - jak wspomniano - sześć pierwszych odnosi się do wydarzeń poprzedzających przyjazd karmelitanek do Lublina oraz do ich podróży z Krakowa na nową placówkę. Księga pisana była konsekwentnie przez kilka kronikarek nieujawniających swoich imion, różniących się jednak zainteresowaniami i sposobami precyzowania przekazu, a także temperamentem i umiejętnościami pisarskimi. Początkowo historiografki odczuwały bardziej wyrazisty imperatyw pisania niż ich następczynie z końca stulecia. Zapiski z pierwszych dziesięcioleci istnienia klasztoru lubelskiego są rozbudowane, narracyjnie jędrne, pisane z pasją. Na okres od 1624 do 1672 r. przypadają 44 rozdziały, a na

i inne księgi, tych ksiąg, co były zbyte, za zezwoleniem Zgromadzenia przez kapitułę wokalną z biblioteki klasztornej udzielając, podpisując i co mogła widzieć służącego do ducha Zakonu naszego potrzebnego dniem i nocą z wielką pracą i usilnie pracując i inne rzeczy...".

46 Jest ona dotąd niewydana, obecnie przygotowywana do edycji.

47 Kronika klasztoru karmelitanek bosych, s. 9.

48 Znalazły się tam również dwa listy karmelitańskie niezwiązane bezpośrednio z klasztorami lubelskimi.

49 Żywot matki Barbary od Najświętszego Sakramentu (Zadzikowej), karmelitanki bosej 1609-1670, oprac. Cz. Gil, Kraków 2013. 
lata 1672-1701 r., zaledwie 6. Kronika karmelitanek w większej części jest spójna wewnętrznie, tak jakby kolejne autorki wzorowały się na poprzedniczkach i w niewielkim stopniu odkształcały metodę dziejopisania. Nadmienić należy, że styl narracji we wszystkich klasztorach żeńskich tego zakonu był zbliżony. Nie można wskazać momentów, w których pióro przejmowały kolejne kobiety, można jednak pokusić się o wskazanie choćby pierwszej z nich.

Karmelitanki tworzyły małe wspólnoty, które mogły liczyć najwyżej dwadzieścia jeden sióstr, choć najczęściej były one kilkunastoosobowe ${ }^{50}$. Nie każda kobieta $\mathrm{w}$ tym wąskim gronie mogła być dziejopiską, a charaktery pisma w certaminach często ukazują dukty koślawe i nieporadne. Według wydawcy, początkową autorką - tą, która stoi za spisaniem Krótkiego opisania - była jedna z pierwszych profesek lubelskiego klasztoru, nie zaś jego fundatorka ${ }^{51}$. Świadczą o tym: znaczny dystans do opisywanych zdarzeń oraz fakt, że jej opowieść jest wyraźnie bezosobowa. Autorka Krótkiego opisania unika dominującej w pozostałych partiach tekstu drugiej osoby liczby mnogiej: „my”. Spotykane są za to sformułowania przywołujące trzecią osobę liczby mnogiej typu: „Mieszkały natenczas zakonniczki nasze klasztoru krakowskiego w Grabiu” ${ }^{2}$. Forma "my” pojawia się po raz pierwszy w opisie wydarzeń z wiosny $1625 \mathrm{r}$. Należy przypuszczać, że wówczas pióro kronikarskie przejęła karmelitanka, która w pełni uczestniczyła już w opisywanych wydarzeniach. Tuż po osiedleniu się w mieście fundatorek do klasztoru wstąpiły: przyjęta w $1625 \mathrm{r}$. wielokrotna przeorysza, od 1630 r. stale pełniąca jakąś funkcję w klasztorze Febronia od Jezusa (zm. 1675) oraz pochodząca z Lublina Beata od Matki Bożej Beatrycze Drzewicka (zm. 1639) $)^{\text {53 }}$. Za pierwszą profeskę uważana jest Teresa od Jezusa Maryi Ligęzina, która przyjechała do miasta z Krakowa wraz z fundatorkami i w Lublinie jako pierwsza złożyła śluby. Potem, do końca lat dwudziestych, w kolejności pojawiły się jako siostry chórowe: w 1628 r. Agnieszka od Trójcy Świętej Myszkowska (zmarła młodo w 1632 r. tuż po opuszczeniu nowicjatu) i w 1629 r. jej rodzona siostra Angela Aleksandra od św. Teresy (zm. 1656) ${ }^{54}$. Przyjmując za słuszne założenie wydawcy, że pierwszą autorką kroniki była profeska, należy skierować uwagę ku Febronii od Jezusa. O jej autorstwie świadczyć mogą dowody pośrednie ${ }^{55}$. O karmelitance

50 Zob. Reguła i konstytucyje zakonnic karmelitanek bosych Zakonu Naświętszej Panny Maryjej z Góry Karmelu, z włoskiego na polski przetłumaczone, Kraków, druk A. Piotrkowczyka, 1635, 1635 (prawdopodobnie błąd druku na karcie 1653), k. Cr.

51 Wydawca zasugerował on, że druga kronikarka pisała mniej więcej do 1654 r. (rozdział 30). Potem kronikarki miały zmieniać się częściej. Wydawca nie podał jednak, na jakiej podstawie wywiódt te wnioski. Cz. Gil, Wstęp..., s. 10.

52 Kronika klasztoru karmelitanek bosych, s. 29.

53 Cz. Gil Stownik polskich karmelitanek..., s. 65.

54 Tamże, s. 58-59.

55 W podobny sposób, czyli metodą eliminacji autorstwa innych sióstr, Karolina Targosz wskazała jako autorkę kroniki krakowskiej konwentu św. Marcina Magdalenę Hipolitównę, zob. K. Targosz, dz. cyt., s. 84. 
tej nie wiadomo zbyt wiele, oprócz tego, że kilkakrotnie była podprzeoryszą, klawiarką ${ }^{56}$, w końcu zaś przełożoną klasztoru św. Józefa ${ }^{57}$. O drugiej z nich, Beacie od Matki Bożej Drzewickiej, wiadomo więcej. Wstąpiła do zakonu jako przeznaczona do prac fizycznych i de facto służenia innym, konwerska, co określało jej status we wspólnocie jako bardzo niski. Następnie ze względu na stan zdrowia opuściła klasztor i ponownie po dwóch latach powróciła do niego w 1628 r. już jako siostra chórowa. Była uczennicą Stobieńskiej, mistrzyni nowicjatu. Sylwetka jej zamieszczona została w Krótkim zebraniu żywota W.M. Anny od Pana Jezusa. Żywot ten w 1656 r. spisał wraz z dołączonym no niego wizerunkiem Drzewickiej historiograf zakonu, Ignacy od Jana Ewangelisty ${ }^{58}$. W kronice józefatek Drzewicka jest bohaterką tylko jednej narracji - dotyczącej jej świątobliwej śmierci. Historia ta ukazuje postać niezwykle naiwną i jest jednym z niewielu przykładów zastosowania żartobliwego tonu w kronice. Autor żywotu Stobieńskiej dodaje kilka obrazków z życia tej siostry, ukazujących jej nader nieskomplikowany wizerunek i predylekcję przede wszystkim do pracy fizycznej, co potwierdza jej pierwotną funkcję w klasztorze. Naszkicowana w żywocie i fragmentach kronikarskich osobowość Drzewickiej raczej wyklucza jej autorstwo kroniki. Najprawdopodobniej to stojąca $\mathrm{w}$ cieniu i nierozpoznana w źródłach Febronia od Jezusa zaczęła prowadzić kronikę w 1625 r., wykazując się wielką żarliwością i zaangażowaniem w odniesieniu do spraw Karmelu, skrupulatną wiedzą na temat konstytucji i przepisów zakonnych, a nade wszystko chętnym i lekkim piórem.

Inną postacią, którą można uwzględnić w poszukiwaniu autorstwa kroniki, była Teresa od Jezusa Maryi Ligęzina. Od początku istnienia klasztoru św. Józefa jej pozycja była w nim wyjątkowa. Ligęzina w statecznym już wieku sprzedała wszystkie swoje majętności i wstępując do klasztoru przeznaczyła je dla polskiego Karmelu. Z tego powodu uznawana była za lubelską fundatorkę i to w podwójnym znaczeniu: jako pierwsza zakonnica na fundacji i jako mecenaska zakonu. Wspomniane cechy pierwszych sześciu rozdziałów dziejów konwentu eliminują ją jednak z grona potencjalnych autorek, ponieważ uczestniczyła ona w wydarzeniach okołofundacyjnych, a zauważalna nieobecność w nich piszącej wyklucza autorstwo Ligęziny.

Tymczasem Febronia od Jezusa już pięć lat po przyjęciu habitu została wybrana podprzeoryszą, co w pewien sposób określa jej kompetencje umysłowe. Po upływie kadencji nastąpiła jej reelekcja, ale niedługo po jej rozpoczęciu, w 1634 r., z niewyjaśnionych w kronice przyczyn siostra Febronia nagle zrezygnowała z funkcji

56 Funkcja klawiarki polegała na pilnowaniu dostępu do kluczy, na które zamykana była skrzynia z najważniejszymi dokumentami klasztornymi.

57 Cz. Gil, Stownik polskich karmelitanek..., s. 57.

58 Ignacy od św. Jana Ewangelisty dokończył pracę zmarłego w 1653 r. Stefana od św. Teresy Kucharskiego. 
zastępowania przełożonej, którą była wówczas Teresa od Jezusa Ligęzina. Pierwsza lubelska profeska sprawowała tę funkcję od 1633 do 1636 r., później zaś pełniła ją pomiędzy 1639 a 1642 rokiem. Prawdopodobnie w 1633 r. doszło do konfliktu pomiędzy Febronią od Jezusa a Teresą od Jezusa Maryi, w którego wyniku pierwsza z nich zrzekła się urzędu. Niedługo potem, w krótkim okresie przerwy w przeorowaniu Ligęziny (1636-1639), podprzeoryszą ponownie została Febronia od Jezusa. Roszada ta nie byłaby czymś nadzwyczajnym, bowiem historia klasztorów karmelitańskich pokazuje, że przez całe dziesięciolecia władzę w poszczególnych konwentach sprawowały naprzemiennie niewielkie grupy zakonnic. W tym jednak przypadku wymiana karmelitanek na urzędzie rzuca światło na tożsamość kronikarki. Pisząca dzieje konwentu we wspomnianym okresie przerwy w przeoracie Ligęziny poświęciła bowiem w tekście duży ustęp opisom nadużyć, jakich miała się dopuszczać ta przeorysza. W $1636 \mathrm{r}$. kronikarka opowiedziała o defraudacjach funduszy, w tym omijaniu konieczności prowadzenia księgowości klasztornej przez przełożoną. Szczególne zgorszenie piszącej budziło też pokątne „dokarmianie” słodyczami młodych zakonnic przez przeoryszę, co do których ta gorliwa matka nie kryła swojej niechęci, a nade wszystko dzielenie się z nimi tym, co było w klasztornej aptece najbardziej godne zainteresowania, czyli wódkami i nalewkami, mającymi status medykamentów ${ }^{59}$ :

[...] czasem też chowała w swojej celi matka przeorysza te rozmaite słodkości i karmiła niektóre młode i nie bardzo potrzebne siostry nimi, a że się z tym chroniła niektórych starszych sióstr, znać, że się to nie miało tak dziać, gdyż refektarz jest naznaczony na jedzenie. Toż i czyniła po celach im roznosząc, kiedy wizytowała ich. A że to młode i dopiero przychodzące tak się zaprawowały w te wygody, gdyż i spanie dłuższe nad zwyczajne godziny, i lekarstw przyuczanie z początku bywało, a przeciwnym sposobem dla chorych sióstr nie było co dać z infimeryjej i inszych potrzeb klasztornych dla żywności i odzieży nie było za co kupićco.

W I657 r., a więc już kilka lat po jej śmierci (zmarła w I654 r.) również Eliasz od Najświętszego Sakramentu, autor jej żywotu, choć w dyskretny sposób, to jednak wspomniał o błędach niedoświadczonego przełożeństwa Ligęziny. Mógł oprzeć swój tekst na kronice oraz świadectwie zakonnic konwentu św. Józefa, którego przeoryszą została w I654 r. właśnie siostra Febronia od Jezusa.

Niechęć piszącej do przeoryszy i osobisty wymiar oceny są w tym fragmencie kroniki bardzo czytelne, a mając w pamięci nagłe odejście z urzędu Febronii od Jezusa, można połączyć te fakty i wskazać właśnie ją jako autorkę kroniki. Splot

59 Kronika klasztoru karmelitanek bosych, s. 70-71. Zob. Cz. Gil, Życie codzienne karmelitanek bosych..., s. 200.

60 Tamże. 
okoliczności personalnych oraz eliminacja autorstwa Drzewickiej pozwalają wobec anonimowej dotąd kroniki lubelskich sióstr $\mathrm{z}$ dużym prawdopodobieństwem mówić o autorstwie nieznanej z nazwiska świeckiego matki Febronii od Jezusa. Trudno wskazać, do kiedy mogła prowadzić kronikę, być może, jak chciał to widzieć wydawca, do lat pięćdziesiątych XVII stulecia - wówczas spójna i równomierna narracja została zakłócona przez wypadki wojenne, a w kronice pojawiły się luki.

$\mathrm{Na}$ ślad Febronii od Jezusa jako autorki kroniki może pośrednio naprowadzić jeszcze jeden trop. Pierwsze karmelitanki były szczególnie wyczulone na zachowanie wierności karmelitańskim zasadom, regułom i konstytucjom. Znajomość zwyczajów i reguł życia zakonnego oraz ich regularna lektura należały do najważniejszych powinności każdej siostry zarówno nowicjuszki, jak i profeski ${ }^{61}$. Wydaje się, że w pierwszym okresie działania klasztoru „nadwrażliwość” na zgodne $\mathrm{z}$ regułą i zaleceniami św. Teresy postępowanie jest bardzo wyraźna. W historii nadużyć matki Teresy od Jezusa podstawą zarzutów, które kronikarka postawiła Ligęzinie, było przede wszystkim sprzeniewierzenie się „zakonnej obserwancyjej”62, choć spod tych „szat wierzchnich” wyzierały i inne, ludzkie emocje. Wyjątkowa gorliwość w odniesieniu do znajomości konstytucji i jej skrupulatnego przestrzegania widoczna jest zwłaszcza u zarania kroniki - w rozdziale siódmym, odnoszącym się do r. I625, gdzie pisząca zamieściła niewielką rozprawę

61 Reguła..., k. f 7 v, rozdz. XXIV, s. 92. Zebranie zwyczajów od WW MM naszych fundatorek i pierwszych matek świątobliwościa sławnych konwentu św. Marcina podane i dotąd chwalebnie zachowane, aby były napotym bez uszczerbku trwajace... spisane roku 1729 (rkps BKB nr 268), O zwyczajach naszych i niektóre ceremonije domowe ( $r k p s$ BKB nr 164) oraz grupa rękopisów precyzujących życie nowicjuszek i nowych profesek, np. Sporządzenie dnia dla nowicyj (rkps BKB nr 167, 168), Rozporządzenie dnia albo praktyka codzienna tak dla nowicyj jako też nowoprofes, karmelitankom bosym wypisane ( $r k p s$ BKB $\mathrm{nr} 70$ ). Wiele tekstów tego rodzaju pochodziło od słynnych mistrzów zakonu, takich jak Jan od Jezusa i Maryi (Juan de San Pedro y Ustarroz; 1564-1615), utwory te były kopiowane rękopiśmiennie. Zalecenia tego rodzaju były również drukowane, z 1653 r. pochodzi Reguła i konstytucyje zakonnic karmelitanek bosych Zakonu Naświętszej Panny Maryi z Góry Karmelu (Kraków, druk Wdowy i dziedziców Andrzeja Piotrkowczyka), zawierający tłumaczenie reguły pierwotnej zakonu, historię powstania tychże reguł oraz tekst konstytucji zakonnych dotyczących zgromadzenia żeńskiego Karmelu. Drukiem ukazał się również podobny tekst, aczkolwiek niemający już charakteru kanonicznego: Ordinarium abo Ceremonijarz Karmelitanek Bosych Zakonu Naświętszej Panny Maryjej z Góry Karmelu według obrzędów Kościoła świętego rzymskiego, z włoskiego języka przełożony (Warszawa 1651). Reguła i konstytucyje zakonnic najwyraźniej wydane zostały z uwagi na wielkie zapotrzebowanie, bo jak argumentował generał zakonu: „konstytucyje miano znowu drukować, dlatego, iż już dawnych nie zstawało". Wydane zalecenia, według rozdziału XXIV, miały być obowiązkowo czytane siostrom w każdym tygodniu, a dodatkowo w każdym klasztorze musiały znajdować się minimum dwa egzemplarze druku bądź kopii rękopiśmiennych tekstu. O innych lekturach karmelitanek zob. H. Popławska, dz. cyt.

62 Kronika klasztoru karmelitanek bosych, s. 70. 
o prawnym umocowaniu klauzury w dokumentach Soboru Trydenckiego ${ }^{63}$ i dała wyraz najwyższego szacunku wobec reguły, zasad i porządku prawnego.

W kronice józefatek nie napotykamy formalnego przyporządkowania rozdziałów do kolejnych lat. Następujące po sobie epizody tworzą spójną i płynną narrację. Poszczególne rozdziały tekstu są numerowane i tytułowane, a tytuły odnoszą się do najważniejszych wydarzeń omawianego okresu, często sygnalizują ciągłość wydarzeń, np. „Rozdział dwudziesty wtóry: Kończy się rzecz zaczęta i o wstąpieniu panny jednej do nas". Znany obecnie tekst nie ma wyraźnego zakończenia, urywa się nagle na początku XVIII w. Tylko nieliczne zachowane do dziś źródła przybliżają strzępy informacji na temat losów lubelskich klasztorów ${ }^{64}$.

Z tekstu kroniki można wnioskować na temat innych źródeł wiedzy piszących o relacjonowanych wydarzeniach. Dominująca forma „my” wskazuje raczej na osobiste uczestnictwo w nich kronikarek. W rozpoczynającym kronikę Krótkim opisaniu informacje przedstawione przez autorkę pochodzą bowiem wyraźnie „Z drugiej ręki”. Niekiedy dziejopiska daje znać, że nie była bezpośrednim świadkiem opisanych zdarzeń, a wiedza na ich temat pochodzi od pośredników. Świadczą o tym np. zapisy dotyczące I658 r. Wówczas karmelitanki, po raz kolejny uciekając z miasta, zamieszkały w Krośnie. W tym czasie Lublin został najechany przez wojska siedmiogrodzkie. Obydwa klasztory stanęły w ogniu. Pomimo nieobecności sióstr w mieście, w kronice zamieszczony został szczegółowy opis tego pożaru. Relacjonując wydarzenie, autorka przytoczyła pełną detali opowieść o tym, jak oddani siostrom karmelici gasili pożogę beczką barszczu i błotem ${ }^{65}$.

63 Tamże, s. 42.

64 W AGAD znajduje się m.in. taki zapis: „W Lublinie nieznośne opresyje. Już nie tylko księży, mieszczan, ale i mniszko chcą [Szwedzi] brać do kurdygardy. Pannę ksienię Piaszczyńską [ksieni bernardynek lubelskich - dop. A. N.-S.] już było kazano wziąć oficyjerowi, która wyźrzawszy wartę i usłyszawszy furyją szwedzką, zemdlała i tym się wyzwoliła. Druga ksieni, karmelitek bosych, matka Kolumba Myszkowska, także miała być wzięta, lecz do kilku dni frysztu sobie uprosiła dla okupu klasztoru swego. Na wszystkie klasztory certum quantum powkładano, nawet na reformatów 5000 talerów. Jednym słowem, sądny dzień w Lublinie, wszystko u szlachty zabierają. [...] Niepodobna wypisać szkód i opresyj, które w kościołach i dworach szlacheckich czynią. Drzewo Krzyża św[iętego] mniejsze wzięli, o większe się koniecznie pytają. [wiadomość z Zamościa i Lublina 4 III 1704 r. - dop. A. N.-S.]", AGAD, Archiwum Publiczne Potockich, , sygn. 57, s. 314; Kolumba od Ducha Świętego Teresa Myszkowska, córka Jana Aleksandra Myszkowskiego starosty tyszowieckiego i Marianny z Pszonków, w klasztorze św. Józefa przebywała od ok. 1666 r., zm. w Lublinie w 1709 r. (zob. Cz. Gil, Słownik polskich karmelitanek..., s. 70). Anna Piaseczyńska, ksieni bernardynek lubelskich (zob. M. Borkowska, Leksykon zakonnic polskich epoki przedrozbiorowej, t. 2, Polska Centralna i Południowa, Wydawnctwo DIG, Warszawa 2005, s. 329).

65 Kronika klasztoru karmelitanek bosych, s. 125. Informacje „z drugiej ręki” odnotowywały również karmelitanki krakowskie, które zamieściły także relacje zakonników o wydarzeniach w klasztorze podczas nieobecności sióstr w mieście, zob. K. Targosz, dz. cyt., s. 230. 
Struktura tej narracji wskazuje, że historia musiała być po powrocie konwentu do Lublina wielokrotnie odtwarzana, powtarzana, przypominana, co zapewne sprawiło, że jej odwzorowanie należy do najbardziej dynamicznych i barwnych opowieści zapisanych w kronice.

Innym źródłem wiedzy o przebiegu zdarzeń są zamieszczone w tekście listy. Naturalny przekaz ustny, oprócz osobistego doświadczenia piszącej, był najważniejszym źródłem wiedzy o wydarzeniach w domu klasztornym. Listy zostały dodane ze względu na przyszłego odbiorcę kroniki i potrzebę uwiarygodnienia historiograficznego. Praktyka zamieszczania epistolografii w przekazach nastawionych na następne pokolenia była typowa dla pamiętnikarstwa, diariuszy i wszelkich form memuarystycznych ${ }^{66}$. Inne kroniki karmelitańskie również zawierały fragmenty epistolograficzne. Najwięcej tekstów tego typu znajduje się w kronikach obydwu konwentów krakowskich. Kronikarki karmelitańskie włączały listy w obręb tekstu jako dokument potwierdzający opisywany moment historyczny, streszczały istotne dla przebiegu narracji listy bądź wspominały o wymianie korespondencji w ważnych dla klasztoru sprawach.

Ze względu na przekazywane treści oraz ich funkcję $\mathrm{w}$ materiale epistolograficznym, należy wyróżnić „listy założycielskie” - dokumentujące formalne pozwolenie na założenie domu i proces fundacyjny, z jednej strony unaoczniające zaangażowanie fundatorów i osób sprzyjających domowi, z drugiej strony pokazujące piętrzące się przed karmelitankami trudności w osiągnięciu celu. Kronikarka klasztoru św. Józefa zamieściła korespondencję pomiędzy legatem papieskim Cosmą de Torres, kardynałem Ludovico Ludovisi (arcybiskup Bolonii, prefekt kongregacji wiary), biskupem Marcinem Szyszkowskim, Janem Marią od św. Józefa Centurione, prowincjałem zakonu oraz generałem z lat I62I-I624, Maciejem od św. Franciszka Hurato de Mendoza, prowincjałem polskim i wizytatorem prowincji. Korpus ten obejmuje w sumie osiem listów, każdy z nich został wprowadzony in extenso. Kronikarka, dążąc do przekazania dialogowości listów, prowadziła potencjalnego czytelnika przez kolejność wydarzeń, np. „Na ten list odpowiedział tak kardynał J[ego] M[iłość] Lodovizy legatowi de Torres z Rzymu 22 dnia stycznia r. tysiącznego sześćsetnego dwudziestego wtórego"67. Listy włoskie zostały opatrzone komentarzem: „Kopia tego listu z włoskiego na polski język przetłumaczonego takowa jest"68.

Podobnie jak w innych formach wypowiedzi historiograficznej - pamiętnikach, diariuszach czy sylwach, również $\mathrm{w}$ strukturze kroniki miało miejsce zamieszczanie

66 Zob. P. Borek, Funkcje listów w barokowych diariuszach i pamiętnikach, w: Epistolografia w dawnej Rzeczypospolitej, t. 1, Stulecie XV-XVII, red. P. Borek, M. Olma, Collegium Columbinum, Kraków 2011, s. 279-294.

67 Kronika klasztoru karmelitanek bosych, s. 19.

68 Tamże, s. 17. 
innych tekstów i gatunków egzogennych ${ }^{69}$. Dotąd mowa była o listach, jednak elementami ożywiającymi opowieść są przede wszystkim krótkie, niekiedy dygresyjne, jednowątkowe mikronarracje - ploteczki szeptane do siostrzanych uszu przez gawędzące kronikarki. Fragmenty te stanowią o nadzwyczajnej wartości literackiej kronik karmelitańskich. Ukazują ekspresję piszących kobiet, umiejętność w zakresie prowadzenia potoczystej narracji i transponowania przekazu oralnego na karty kroniki.

Karmelitanki prowadzące zapiski pokazały w ten sposób galerię nietuzinkowych postaci zamieszkujących klasztorne mury. Poświęciły im wiele uwagi, i co szczególnie interesujące, były to w większości bohaterki negatywne. Opowieści o nich miały wyraźnie skandalizujący posmak. Można wspomnieć o regularnie uciekającej zakonnicy „grubego stanu”, która wykazując nadludzką siłę, wydostawała się przez parkan do miasta, naga protestowała w oknie celi, nawoływała pomocy świeckich, wymyślała przełożonej, wyrywała się z łańcuchów, aż w końcu czmychnęła po spuszczonych z okna prześcieradłach, aby po kilkumiesięcznym świeckim, hulaszczym życiu wrócić skruszoną do klasztoru ${ }^{70}$. Rozpoczynając tę niebywałą opowieść, kronikarka starała się nadać narracji ton pouczający:

Acz Pan Bóg przeplatać rzeczy wesołe z smutnymi i na pokaranie grzechów naszych nie tylko choroba tejże siostry, która nam przyczyną była żalu niemałego, ale nadto przypuścił na nas Pan nasz przypadek straszny, dotąd w klasztorach naszych niesłychany, że jedna z naszych sióstr, konwierska, dwie lecie mając po profesyjej, apostatką została i uciek[ł]szy od Boga z klasztora swojego pozbawiła się konwersacyjej Boskiej i towarzystwa niebieskiego ${ }^{71}$.

Rozbudowana historia niepokornej siostry została opisana aż na dziewięciu stronach. Autorka, trzymając się zacytowanego założenia, starała się zrównoważyć skandaliczną wymowę tej opowieści, dodając natychmiast drugą, o innej, chwalebnej ucieczce - niejakiej panny Drzewickiej - tym razem do zakonu ${ }^{72}$. Panna ta miała salwować się ucieczką do klasztornego raju od okrutnej wobec

69 Zob. P. Borek, Funkcje listów w barokowych diariuszach...s. 282.

70 Kronika klasztoru karmelitanek bosych, s. 72-73.

71 Tamże, s. 70-71.

72 Historia Agnieszki Drzewickiej nie jest jasna. Czesław Gil podaje, że opisywaną w tym miejscu karmelitanką była Agnieszka Drzewicka, podczas gdy informacje ze Słownika polskich karmelitanek... tego autora nie potwierdzają historii o ucieczce panny ani o innowierczym pochodzeniu jej okrutniej matki, która, w świetle kroniki, miała ją bić i zmuszać do przebywania w towarzystwie innowierców. Gil wskazuje jako źródło Compendium vitae ac virtutum venerab[ilis] Matris Beatae Columbae a Puero Jesu Monasterii Lublinensi (Archiwum Generalne w Rzymie, rkps 94b). Ponadto dane z Archiwum Generalnego mówią o osieroceniu przez matkę dziecka w wieku 11 lat. 
niej i zatwardziałej w innowierstwie matki. Pomimo że kronikarki opatrywały tego typu historie pouczającymi konstatacjami, wyraźnie widać jednak, iż nie pareneza była dla piszących najważniejsza, ale spektakularność historii oraz emocje im towarzyszące.

Z pisarskim zacięciem opowiedziana została historia aroganckiej i niepokornej wobec reguł zakonnych panny Uszyńskiej, wyrzuconej ostatecznie za niesubordynację przez Annę od Jezusa ${ }^{73}$. Jedną z najbarwniejszych jest opowieść o morderczyni, pannie Sczawińskiej ${ }^{74}$, zakonnicy-czarownicy znanej ze swych niecnych praktyk lubelskim medykom. „Trefna” nowicjuszka miała próbować otruć swego ojca i macochę. Słabo sprawdzająca się w postępach duchowych w klasztorze, została przeznaczona do prac domowych, ale - jak się niebawem okazało - zajmowała się tu zwłaszcza zbieraniem tajemniczych ziół i czarną magią. Według kronikarki, jej działania sprawiły, że wkrótce zachorowały wszystkie zakonnice $\mathrm{w}$ konwencie. Sczawińska została wyrzucona $\mathrm{z}$ klasztoru, a wychodząc, miotała diabelskie przekleństwa pod adresem jego mieszkanek.

Historia tej panny, notabene nieodnotowanej w źródłach historycznych, pokazuje pewną interesującą cechę kronikarskich mikronarracji. Zestawienie niektórych szczegółów wydarzeń pokazuje brak logicznej spójności w tej opowieści. Autorka wyraźnie kontaminuje różniące się przekazy wydarzeń, ich wersje czy po prostu plotki. O kobiecie raz mówi się, że pochodziła z daleka, innym razem, że była znana w środowisku lubelskich medyków; miała otruć ojca i macochę, jednak ci sami odebrali niebezpieczną pannę z klasztoru; zakonnice wyrzuciły ją ze zgromadzenia, ale jednocześnie poprosiły zbrodniarkę podejrzewaną o wywołanie choroby całego konwentu o ocenę wymiocin (sic!) chorych; zaś przeklinająca je czarownica $w$ tym samym czasie posłała chorym antidotum na truciznę. Z tego zestawienia sprzecznych elementów narracji wynika, że nie prawda i fakty są najważniejsze w tej opowieści, ale poruszenie i zbiorowe emocje, jakie wzbudziły opisywane wydarzenia. Rozbieżność wersji można łączyć z oralnym obiegiem tej historii w obrębie małego środowiska, jakim był klasztor. Kronikarka z pasją oddała grozę, którą wywołał zakonny czarny charakter. Nadmienić można, że jest to jeden $z$ bardzo niewielu przypadków w tekście, w których widać, że karmelitanki ze swoją wspólnotą usytuowane były w szerszej przestrzeni społecznej: ludzi z miasta, felczerów, anonimowego tłumu "przed kołem”75. Historia ta pokazuje też, jak sprawy „z miasta” przenikały za klasztorny mur:

73 Kronika klasztoru karmelitanek bosych, s. 88-91.

74 Nie odnotowuje jej autor Słownika polskich karmelitanek....

75 Tak zwane „koło” było instalowanym w rozmównicy urządzeniem, mechanizmem służącym do kontaktowania się, odbywania rozmów i przekazywania sobie rzeczy pomiędzy karmelitanką, która nie mogła być widziana, a osobą z zewnątrz. Przestrzeń „przed kołem” oznaczała przestrzeń poza klauzurą. 
Tych znaków i mów trudno było nie domyślać się tym ludziom, co się koło nas bawili przed kołem i samiż się tam więcej od domowych tej panny nasłuchali o jej sprawach niedobrych ${ }^{76}$.

Osobną grupę stanowią opowieści o pannach, które uciekły z domu do klasztoru wbrew swym rodzicom. Oprócz wspomnianej Drzewickiej, po cichu do klasztoru miała się udać Zofia Myszkowska - Agnieszka od Trójcy Świętej77, a pod koniec XVII w. niejaka panna Grochowska. Komentarz zamieszczony przez kronikarkę przy opowieści o tej ostatniej ${ }^{78}$ oraz funkcjonujące w obiegu karmelitańskim inne opowieści o „świętych uciekinierkach"79 pokazują, że ucieczki panien do zakonu były $\mathrm{w}$ tej epoce samodzielnym toposem narracji zakonnych. Interesujące jest to, że oficjalne żywoty Drzewickiej i Myszkowskiej nie potwierdzają faktu ucieczki. Możliwe, że kronikarki ubarwiały więc na potrzeby czytelniczek „za murem” swoje opowieści, utwierdzając tym samym domowniczki w ich życiowym wyborze.

Oprócz zbioru opowieści o współsiostrach, kandydatkach, uciekinierkach, wyrzutkach, odrębną grupę małych narracji stanowią narracje "przygodowe” - historie opisujące niebezpieczeństwa, które przytrafiły się konwentowi. Tu wyróżniają się historie o pożarach i „strasznych” wydarzeniach podróżnych. W XVII w., w świetle kroniki, zakonnice opuszczały swój klasztor aż piętnaście razy. Przyczyną były tak wojny, jak i regularnie nawracające w Lublinie epidemie. Niektóre podróże karmelitanek miały przygodowy, czasem wręcz dramatyczny charakter, a opisane zostały z prawdziwą swadą. Pośród przygód zasłoniętych woalami zakonnic warto przypomnieć zwłaszcza opowieść o topieli w podlubelskiej Ciemiędze, tak naprawdę niewielkiej rzece, ale w opowieści urastającej do wody potężnych rozmiarów. Historia przekazana przez karmelitankę podaje kilka dynamicznych obrazów. Pisząca opowiedziała w narracji pełnej ekspresji o rozległych błotach, po których biegła na ratunek czeladź, wywróconych do góry kołami wozach, ratujących się z wody spłoszonych koniach. Odwzorowała też dramat niemal tonących zakonnic. Znakomitym kontrapunktem całej opowieści jest zestawienie literackiego obrazu anielskiej karmelitanki cicho umierającej pod wodą i pokornie witającej się z wiecznością, z wrzaskiem czy wręcz rykiem siostry probantki, „która miała wielki głos i mocny, że lecąc z mostu w rydwanie zakrytym, jakoś oknem głowę i ręce wyjęła i czegoś się uchwyciła, sama w wodzie będąc, poczęła zaraz wołać głosem wielkim: »ratunku«!"8o.

76 Kronika klasztoru karmelitanek bosych, s. 119.

77 Zob. Cz. Gil, Słownik polskich karmelitanek..., s. 58.

78 Kronika klasztoru karmelitanek bosych, s. 172.

79 Do zakonu w spektakularny sposób miały uciec m.in.: Marianna Marchocka, Petronela Mikuliczówna i inne panny, zob. Cz. Gil, Stownik polskich karmelitanek....s. 27-30, 38-39; K. Targosz, dz. cyt., s. 115.

80 Kronika klasztoru karmelitanek bosych, s. 134. 
Karmelitanki od św. Józefa wielokrotnie doświadczyły niebezpieczeństwa pożaru. Opowieści o pożogach stanowią kolejną grupę znakomicie opowiedzianych historii. Wszystkie małe narracje wplecione w tok pamiętnikarski łączy poczucie zagrożenia: albo pochodzącego z wewnątrz (pożary, osoby niosące niepokój), albo wynikającego z zewnętrznego usytuowania bohaterek (niebezpieczne przygody w podróży). Przeciwwagą są dla nich opisy śmierci zakonnic, jednak te przykładne, budujące wizerunki wzorcowe, utrzymane są w poetyce ars bene moriendi i wyraziście nacechowane hagiograficznie. Jednak takich „pozytywnych” opowieści, równoważących pierwszy typ mikronarracji, jest zdecydowanie mniej.

Przez klasztor św. Józefa przewinęły się wyjątkowe postaci kobiet, jak choćby znane ze swoich wizji i uniesień mistycznych: Stobieńska czy Zadzikowa. Nigdy te słynne karmelitanki nie stały się jednak pierwszoplanowymi bohaterkami kroniki. Wszystkie autorki konsekwentnie za głównego bohatera opowieści zawsze uznawały zbiorowość - całą wspólnotę klasztorną.

Dziejopisarstwo zakonne narracyjnie rozbudowane i wciągające do wyizolowanego świata za murem, przywołuje styl gawędowy. Autorki prowadzą relację w sposób naturalny, swobodny, niekiedy dygresyjny. Często sięgają też po elementy mowy wprost, posługują się typowymi dla gawędy określeniami: „tedy”, „zatem”, „tegoż roku”, sygnalizują początek mikroopowieści słowami - „a to było tak:...” czy - „A, że w[ielebny] ociec przeor nie mógł odjachać, ta była przyczyna: jachałyśmy przy jej mci dwiama wozami..." lub też dają znać, że opowiadanie mogłoby jeszcze trwać długo, ale inne rygory nakazują im je zakończyć czy też zaznaczają, iż są rzeczy, których nie godzi się pominąć. Tak jak w rozmowie z nieobecnym odbiorcą, kronikarki pokazują również własną dyskrecję, sygnalizują wiedzę szerszą niż to, na co pozwala im papier, znajomość rzeczy, o których nie wypada pisać, co tym samym nadaje opowieści posmak plotki.

Gawędowy ton zapisków kieruje uwagę literaturoznawców w stronę pamiętnikarskich cech kroniki, a kulturoznawców ku kategorii prywatności, tożsamości i pamięci tej niewielkiej grupy kobiet odizolowanych w znacznym stopniu od świata.

Kronika, w przeciwieństwie do dziejopisarstwa karmelitów, pisana była po polsku - karmelitanki słabo znały łacinę, uczyły się jej tylko w nieznacznym stopniu do celów liturgicznych, a w zachowanych rękopisach i zasobach bibliotecznych język wczesnonowożytnej nauki jest bardzo słabo reprezentowany. Kroniki domowe, choć ich fragmenty czy kopie udostępniano poza konwentem, były kierowane przede wszystkim do mieszkanek domu, w którym powstały, tworzono je na „użytek wewnętrzny”, dla kolejnych pokoleń panien. Zapisy miały pełnić funkcję medium komunikacyjnego między pokoleniami ${ }^{81}$. Nastawienie na sukcesorów było charakterystyczne dla pamiętnikarstwa siedemnastowiecznego. Podobnie jak

81 Zob. R. Krzywy, Funkcje komunikacyjne staropolskiego pamiętnika. Na przykładzie zapisków moskiewskich Stanisława Niemojewskiego, w: Z dziejów staropolskiego pamiętnikarstwa..., s. 125-140. 
ta dziedzina piśmiennictwa, niejednokrotnie eksponująca przywiązanie do rodu i jego kult, patriarchalną ideologię, niezbywalną istotność wydarzeń i wyjaskrawienie tego, co prawidłowe i mieszczące się w ramach przyjętych norm, nie zaś indywidualne i jednostkowe, tak i kronika zwracała uwagę przede wszystkim na zakonne elementy wspólnotowe, związane z ustalonym porządkiem i wartościami wzorcowymi.

Zapiski klasztorne nieczęsto wskazują potencjalnego czytelnika tekstu. O programowanym odbiorcy kronika niemal nigdzie nie wspomina. Zaledwie raz, w Przemowie do Krótkiego opisania, rozpoczynająca tekst „uczona” autorka wyraziła nadzieję, że rozpoczęte dzieło będzie w przyszłości kontynuowane, co jednoznacznie wskazuje też czytelników wśród przyszłych pokoleń:

Abyśmy tedy dosyć wolej Bożej uczynili, nie szukając nic inszego, tylko samej chwały Bożej, postaramy się krótko opisać, jako się to założenie klasztoru panieńskiego w Lublinie stało, a napisawszy to, ci, którym potym będzie zaś należało, zawsze będą powinni przyczyniać, jeśli co znacznego w tym klasztorze pokaże, i po śmierci swojej opisać dobre przykłady i świątobliwe dzieje tych, które znacznie do świątobliwości ciągnęły ${ }^{82}$.

Dziejopisarstwo traktujące o „domu kobiet” - jak pamiętamy - liczącego najwyżej dwadzieścia jeden sióstr, pełniło również funkcje „wysokie”: upamiętnienia pionierek i podkreślenia wyjątkowości ich celów, wartości, desperacji, trudności, pokonywania przez nie przeciwności losu czy raczej nieustannie dostrzeganego działania szatana. Do wzniosłych motywacji zaliczyć należy też cele parenetyczne, projektowane jako działanie wychowawcze i formacyjne, nakierowane na przyszłe bosaczki. Rozpoczęciu narracji przyświecała świadomość dzieła nadzwyczajnego, a patetyczność wzmacniała paideutyczny przekaz tekstu. Podniosłość objawiała się w uroczystym, inicjalnym określeniu czasu historycznego, dynastycznego, ze wskazaniem papieża i króla polskiego, cesarza, oraz sprecyzowaniu roku panowania polskiego władcy.

Jednak szczytne założenia parenetyczne najbardziej wyraziste są w zapiskach dotyczących pierwszej połowy XVII w., pierwszego etapu działania konwentu. Z biegiem lat wychowawczy cel i pouczający ton zapisków zanikły, a ich miejsce zajęła opowieść - gawęda o życiu „za murem”. Kronika klasztorna stała się bliższa domowej, intymnej księdze, w której przechowywana jest pamięć rodziny. Nie jest wykluczone, że narracja uległa przemodelowaniu ze względu na zmieniające się potrzeby i autorek, i czytelniczek przekazu. W miarę upływu lat zakon wpisał się w religijny krajobraz, klasztory w przestrzeń miasta, a pierwotny zapał pionierek Karmelu nieco przygasł. Zestawienie początkowych fraz testu $z$ ostatnimi frag-

82 Kronika klasztoru karmelitanek bosych, s. 13. 
mentami tekstu pokazuje, że kronika ewoluowała od historiograficznego zapisu spraw wielkich do pamiętnikarskiego utrwalania codziennych problemów związanych z murem, dzierżawcą, dobrodziejem, ludźmi, rzeczami, instytucjami i własnym zgromadzeniem w bieżących sprawach.

Karmelitanki od św. Józefa ani razu nie użyły jakiegokolwiek określenia przybliżającego ich własne rozumienie uprawianego piśmiennictwa. Termin „kronika” w odniesieniu do dziejopisarstwa karmelitanek pochodzi z XX wieku, od momentu edycji Rafała Kalinowskiego poczynając, a na współczesnych badaczach i edytorach kończąc. W dotychczas poczynionych przeze mnie uwagach na temat zapisków karmelitanek lubelskich pojawiają się wymiennie terminy: „kronika”, „historiografia” i „dziejopisarstwo”. Do zbioru określeń gatunkowych ${ }^{83}$ odnoszących się do pracy tych kobiecych autorek należy dodać jeszcze „pamiętnik” i najszerszy, dotyczący zjawisk memuarystycznych termin - „egodokument”. Kroniki pełnią funkcję zbiorowego pamiętnika zgromadzenia ${ }^{84}$, księgi domowej mającej te same funkcje, co staropolskie memuary ${ }^{85}$.

Jak zauważono, memuarystyka staropolska do XIX w. nie była skodyfikowanym obszarem piśmiennictwa, a terminy „kronika”, „diarusz”, „transakcyja”, „dzieje” i inne pokrewne określenia były używane wymiennie ${ }^{86}$. Z pamiętnikarstwem łączy kronikę klasztorną pragmatyczny charakter piśmiennictwa i nakierowanie na wąską, rodzinną grupę odbiorców. Kronika klasztoru św. Józefa spisywana była retrospektywnie niezbyt długo po opisywanych wydarzeniach ${ }^{87}$. Wskazane źródła wiedzy kronikarek - autopsja, przekaz oralny, załączone dokumenty pozatekstowe - również sugerują powinowactwo $\mathrm{z}$ memuarystyką ${ }^{88}$. O związkach z tą dzie-

83 O gatunkowości kronik klasztornych na przykładzie kronik grodzieńskich zob. H. Pavlouskaya, Grodzieńskie kroniki klasztorne XVII i XVIII wieku. Formy gatunkowe i aspekty komunikacyjne, https://depotuw.ceon.pl/bitstream/handle/item/40o/PAULOUSKAYA\%20DOKTORAT.pdf?sequence=1 [dostęp: 20.05.2018]; J. Przyklenk, Staropolska kronika jako gatunek mowy, Wydawnictwo Uniwersytetu Śląskiego Katowice 2009; S. Roszak, Archiwa sarmackiej pamięci. Funkcje i znaczenia rękopiśmiennych ksiąg silva rerum w kulturze Rzeczpospolitej XVIII wieku, Wydawnictwo Uniwersytetu Mikołaja Kopernika Toruń 2004, s. 197 i nast.

84 Zob. K. Targosz, dz. cyt., s. 14.

85 O dyskusji na temat cech pamiętnikarstwa, różnorodności określeń gatunkowych, funkcji oraz zakresu piśmiennictwa w ujęciu A. Sajkowskiego, M. Kaczmarka, J. Trzynadlowskiego, J. Rytel, R. Lubaś-Bartoszyńskiej. Zob. P. Borek, O polskim pamiętnikarstwie doby baroku, w: Z dziejów staropolskiego pamiętnikarstwa. Przekroje i zbliżenia, red. P. Borek, Collegium Columbinum, Kraków 2012, s. 31-52. Funkcje komunikacyjne pamiętnikarstwa staropolskiego omówił R. Krzywy, dz. cyt.

86 Zob. tamże.

87 Nie wszystkie spisane w epoce staropolskiej kroniki klasztorne miały taki charakter, np. norbertanki imbramowickie prowadziły zapiski diariuszowe, uzupełniane co kilka dni (por. Kronika klasztorna sióstr norbertanek w Imbramowicach 1703-1741, wyd. W. Bielak, W. Żurek, Kielce 2016).

88 J. Trzynadlowski oddzielił przekaz diarystyczny od pamiętnikarskiego ze względu na jego źródła i metodę relacjonowania, jednak podziały te nie są współcześnie podejmowane (zob. P. Borek, O polskim pamiętnikarstwie doby baroku..., s. 33). 
dziną piśmiennictwa świadczy nakierowanie na przyszłe pokolenia mieszkanek domu i członkiń rodziny, to jest konwentu, oraz parenetyczne nastawienie, choć nierównomiernie w tekście rozłożone. Bohaterem zbiorowym jest niewielka grupa kobiet, które łączą wewnętrzne reguły, zobowiązania - śluby, oraz wspólna przestrzeń. Łączy je również tradycja budowana właśnie m.in. przez domową kronikę. $\mathrm{Na}$ wspólnocie skupiona jest cała uwaga piszącej i - jak wspomniano uprzednio - żadna $\mathrm{z}$ jednostkowych bohaterek nie dominuje w narracji. Za pamiętnikarskim charakterem tekstu przemawiają również chronologiczny przyrost informacji oraz przyczynowo-skutkowe następstwa wydarzeń. Zapisy klasztorne sytuują się bardzo blisko kategorii pamiętnika - w ujęciu wszystkich badaczy gatunku, bez względu na szczegółowe różnice pomiędzy teoriami - i reprezentują wszystkie funkcje pamiętnikarstwa ${ }^{89}$.

Kronikarki wielokrotnie sygnalizowały, jak istotną wartością jest dla konwentu tożsamość grupy. Konfrontacje my - oni, wewnątrz - zewnątrz (klasztoru), podkreślanie indywidualizmu i odmienności zakonu, ambicja nieporównywalności z jakimikolwiek innymi grupami, przeświadczenie o swoistym „wybraństwie Karmelu" "o pokazują daleko idącą autoświadomość autorek. Cecha ta jest uznawana za jeden z kluczowych wyróżników egodokumentu".

Wskazując na pamiętnikarskie cechy kroniki domowej karmelitanek bosych, należy pamiętać jednak i o historiograficznych ambicjach tekstu. W kronice sióstr od św. Józefa dostrzegalne jest napięcie pomiędzy koniecznością dziejopisarską a naturalną skłonnością do epickiej narracji czy intymnej opowieści. Historiograficzne ciążenie widoczne jest zwłaszcza na początku Krótkiego opisania, gdzie wyrazista jest już wspomniana kategoria wzniosłości. Rozpoczęcie kroniki słowami św. Teresy i ustępem ze Starego Testamentu wzmacnia przekaz i rangę wydarzenia. Tego typu autorytety nigdzie później w tekście się nie pojawiają. O historiograficznych założeniach kroniki świadczy też rytm opisów elekcji wewnątrzklasztornych czy zakonnych.

Zapisy karmelitanek od św. Józefa są najobszerniejszym tekstem pochodzącym $\mathrm{z}$ tego lubelskiego środowiska. Nie jest to natomiast jedyny wywodzący się z niego zapis kronikarski. Unikalny charakter ma zachowany fragment kroniki drugiego lubelskiego konwentu, Krótkie opisanie fundacyjej klasztoru karmelitanek bosych w Lublinie, pod tytułem Najśw[iętszej] P[anny] Maryjej Niepokalanego Poczęcia $R[o k u] P[a n ́ s k i e g o]$ 1649. Dnia 11 kwietnia. Jego odpis znajduje się w omówionym już rękopisie - Księdze fundacyj klasztorów karmelitanek bosych prowincji polskiej

89 P. Borek, O polskim pamiętnikarstwie doby baroku..., s. 31-50.

90 Zob. A. Nowicka-Struska, Dom i świat...s. 187-208.

91 Zob. S. Roszak, Od „piśmiennictwa przestrzeni prywatnej” do Villi Vigoni. Z doświadczenia europejskich zespołów badawczy egodokumentów, w: Memuarystyka w dawnej Polsce, red. P. Borek, D. Chemperek, A. Nowicka-Struska, Collegium Columbinum, Kraków 2016, s. 9-18. 


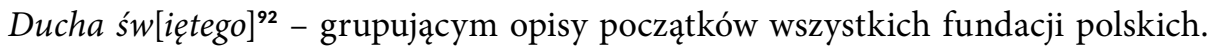
Zapis kroniki fundacji nie ujawnia autorki tekstu. Na koniec należy poświęcić nieco uwagi tej „małej kronice”, zwłaszcza że nie została ona dotąd wydana ${ }^{93}$.

Jak wspomniano, wydawca kroniki konwentu św. Józefa sceptycznie wyraził się w ogóle o istnieniu kroniki drugiego lubelskiego klasztoru ${ }^{94}$. Kilka przesłanek świadczy jednak o tym, że księga ta istniała. Pierwszą są dołączone do kroniki konwentu józefatek fragmenty - luźne karty o wyraźnie dziejopisarskim charakterze, odnoszące się do dziejów poczętek. Edytor wydał je wraz z kroniką konwentu św. Józefa, lokalizując w rozdziale trzydziestym ${ }^{95}$. Dwa fragmenty zapisków zawierają również kopie dwóch listów: podprzeoryszy poznańskiej, Franciszki Teresy od Wniebowzięcia Najświętszej Marii Panny i Kolumby od Ducha Świętego, przeoryszy warszawskiej, skierowanych do przełożonej konwentu Niepokalanego Poczęcia Najświętszej Marii Panny, Teresy Barbary od Najświętszego Sakramentu. Teksty te odnoszą się do wydarzeń z 1655 r.

Drugim argumentem przemawiającym za istnieniem tej kroniki jest pewien uzus, który skłaniał do prowadzenia tego rodzaju księgi w klasztorze. Nie ma podstaw, by sądzić, że zakonnice - fundatorki wywodzące się z klasztoru (św. Józefa), w którym pisano kronikę, a w przyszłości założycielki konwentu (poznańskiego), w którym obyczaj ten również był praktykowany, nie podjęły podobnych działań.

Istnienie współcześnie zaginionej kroniki sugerował też Karol Górski przy okazji analizy materiałów, które otrzymał niegdyś od karmelitanek krakowskich jako żywot Teresy Barbary od Najświętszego Sakramentu ${ }^{96}$. Dowód istnienia kroniki poczętek odnaleźć można w żywocie tej przeoryszy W jego tekście wyodrębnić można wyraźne dziejopisarskie fragmenty, przypominające techniką narracji inne kroniki karmelitańskie, zwłaszcza zaś lubelską z klasztoru pw. św. Józefa. Kronikarski charakter mają w hagiograficznym utworze części odnoszące się do lat 1649 - ca. $1655^{97}$. Fragmenty te wyróżniają się chronologicznym uporządkowaniem, które nie jest cechą epizodycznego i podzielonego raczej tematycznie żywotu. Ponadto, w przeciwieństwie do reszty tekstu dotyczącego słynnej przeoryszy, tylko w tych miejscach dominuje forma „my” w odniesieniu do zbiorowego bohatera - konwentu.

Żywot Teresy Barbary od Najświętszego Sakramentu powstał niedługo po jej śmierci w $1670 \mathrm{r}$. Wydawca tekstu opowiedział się za najbardziej prawdopodobnym autorstwem żywotu - Marii Magdaleny od Zbawiciela ${ }^{98}$. Podobnie jak w kronice

92 Rkps BKB 255, k. 118-123.

93 Obecnie przygotowywana jej edycja tekstu.

94 Cz. Gil, Wstęp, w: Kronika karmelitanek bosych klasztoru św. Józefa..., s. 7.

95 Kronika klasztoru karmelitanek bosych, s. 103-116.

96 K. Górski, M. Borkowska, Hagiografia zakonna a wzorce świętości w XVII wieku..., s. 11.

97 Tamże, s. 90-121-133, 166.

98 Anna Żaboklicka, (1608-1677), córka sędziego sochaczewskiego, w klasztorze św. Józefa przebywała od 1633 r. Powierniczka, równolatka, sekretarka i zastępczyni Teresy Barbary 
józefatek, fragmenty te znamionuje naturalny i swobodny bieg opowieści. Autorka tego spisanego w Poznaniu tekstu nie mogła mieć dostępu do przechowywanej w Lublinie kroniki poczętek. Kronikarski tok narracji odnoszącej się do dziejów konwentu Niepokalanego Poczęcia Najświętszej Marii Panny mógł wynikać jednak z tego, że to właśnie Maria Magdalena od Zbawiciela pełniła wcześniej funkcję dziejopiski w latach zamieszkiwania w klasztorze Niepokalanego Poczęcia. Za jej autorstwem, zarówno żywotu Zadzikowej, jak i „małej kroniki” poczętek, przemawiają jej wypróbowane wcześniej umiejętności pisarskie. Żaboklicka, która wyjechała w 1638 r. jako fundatorka do klasztoru wileńskiego, pozostawiła diariusz tej podróży99. Prowadzone na bieżąco zapiski stały się podstawą późniejszego opisu fundacji klasztoru litewskiego i kroniki prowadzonej już przez inną karmelitankę (Katarzynę od Chrystusa Tyszkiewiczównę). Ponadto Maria Magdalena od Zbawiciela pozostawiła osobiste, sylwiczne modlitewniki ${ }^{100}$, zdradzające nietuzinkową osobowość o szerokich horyzontach intelektualnych.

Opis fundacji klasztoru Niepokalanego Poczęcia Najświętszej Marii Panny jest tekstem o niewielkich rozmiarach, znacznie bardziej lakonicznym niż analogiczne fragmenty kronik innych klasztorów w Polsce. Przekaz „małej kroniki”, zachowany do chwili obecnej dochowany do współczesności, pochodzi, jak to już zostało opisane, z początku XVIII w. Najprawdopodobniej został on przepisany na potrzeby rękopisu Cecylii Teresy od Ofiarowania ${ }^{101}$ przez lubelską karmelitankę, która wówczas nieznacznie uzupełniła tekst. Znajduje się w nim bowiem następujące wtrącenie, odnoszące się do kościoła poczętek: „Przyszedłszy na miejsce, w kościółku, natenczas jeszcze drewnianym"102. Pierwsze karmelitanki nowej fundacji w niejakim pośpiechu wprowadzały się do nowej siedziby organizowanej przez Daniłowiczów, a ich tymczasowy kościół, w przeciwieństwie do klasztoru, który był niemal skończony, pozostawał drewniany. Nieznana jest dokładna data ostatecznego wymurowania nowego kościoła, ale jego konsekracja miała miejsce dopiero $\mathrm{w} 1721 \mathrm{r}^{103}$, co oznaczałoby, że uwagę tę poczyniła już osiemnastowieczna zakonnica.

Tekst obejmuje zaledwie sześć kart. W ich obrębie znalazły się informacje z okresu 1645-1649. Dotyczą one wydarzeń związanych z założeniem fundacji, to jest wmurowaniem kamienia węgielnego, przerwy w działaniach fundacyjnych,

od Najświętszego Sakramentu, wielokrotna podprzeorysza i przeorysza klasztorów lubelskiego i poznańskiego (zob. Cz. Gil, Słownik polskich karmelitanek..., s. 60-61).

99 Archiwum Prowincji Karmelitów Bosych, rkps AKBW 22 (Archiwum Karmelitanek Bosych Wilno).

100 Chodzi m.in. o rkps BKB 219. Fragmenty jej zapisków znajdują się tez w kilku innych rękopisach Biblioteki Karmelitanek Bosych.

101 BKB rkps 255.

102 BKB rkps 255, k.120.

103 J.B. Wanat, Zakon karmelitów bosych w Polsce..., s. 654. 
wynikającej z wydarzeń politycznych $1648 \mathrm{r}$. i konieczności ucieczki zakonnic z Lublina. Następnie przedstawiona została szczegółowa relacja z wydarzeń od 9 do 14 kwietnia 1649 r., kiedy miały miejsce przenosiny karmelitanek do nowej siedziby i pierwsze dni w niej spędzone. Najprawdopodobniej relacja ta powstała nie później niż w 1650 r. Pisząca nie odnotowała ważnych dla karmelitanek wydarzeń, jakimi były: śmierć Daniłowicza w 1650 r. i jego żony w 1653 r. Fundatorzy wraz ze słynnym mistycyzującym teologiem i pisarzem karmelitańskim Stefanem od św. Teresy Kucharskim (zm. 1653) zostali pochowani w prezbiterium kościoła Niepokalanego Poczęcia Najświętszej Marii Panny. Okoliczności ich śmierci zostały natomiast bardzo szczegółowo i w stylu prawdziwie kronikarskim opisane w żywocie Teresy Barbary od Najświętszego Sakramentu.

O tym, że Krótkie opisanie spisane było w niezbyt dużej odległości czasowej od przedstawionych wydarzeń, świadczy wyjątkowa mnogość utrwalonych tu detali. Uszczegółowienie dotyczy uroczystego pieszego przejścia obecnych gości, konceptu kaznodziejskiego, muzyki, pewnych rozwiązań technicznych, skandalicznych okoliczności przenosin ${ }^{104}$, stroju pierwszej nowicjuszki przyjętej do konwentu. Nadmienić można, że tak precyzyjnie opisane przenosiny zaledwie trzech karmelitanek miały miejsce w bardzo niewielkiej przestrzeni topograficznej, bowiem obydwa klasztory dzieli w Lublinie ok. 250 metrów.

Narracja utrzymana jest w porządku chronologicznym, autorka stara się wiernie oddać dzień po dniu wypadki z kwietnia 1649 r., zwłaszcza moment faktycznej inicjacji klasztoru. Ujawnia przy tym swoje autorskie „ja” - uczestniczki wydarzeń: „Wracam się do tego dnia, [podkr. A.N.-S.] w którem stanęła klauzura, iż będąc te matki pełne wesela Ducha Przenajśw[iętszego] w wielkim ubóstwie zaczynały tę fundacyją" ${ }^{105}$.

W Krótkim opisaniu naprzemiennie i nieregularnie pojawiają się formy „my” w dwóch znaczeniach: zakonnice nowego konwentu i zakonnice klasztoru św. Józefa (one - w obiektywizującym i grzecznościowym odniesieniu do fundatorek klasztoru, ale także w odniesieniu do zakonnic konwentu św. Józefa) oraz pojedyncze ,ja”. Pisząc o wydarzeniach z lat 1645-1648, autorka używa ponadto zaimków „my” i „nasz” - „musieliśmy z klasztoru naszego św. Józefa uchodzić”, co zdradza jej wcześniejszą przynależność do niego. Wielokrotne poświadczenie jej współuczestnictwa w życiu klasztoru św. Józefa dowodzi, iż była ona jedną z tych zakonnic, które przeszły do nowej fundacji.

Fundatorka klasztoru Niepokalanego Poczęcia Najświętszej Marii Panny Daniłowiczowa postanowiła przenieść do nowej placówki najbardziej wartościowe, charyzmatyczne i intelektualnie wyrobione zakonnice, które miały budować klimat duchowy nowego konwentu. Przenosiny zostały odmiennie ujęte w kronice

104 BKB rkps 255, k. 121.

105 Tamże. 
józefatek, poczętek i w żywocie Zadzikowej. O ile pierwsza kronika odnotowała ten fakt dosyć neutralnie, oficjalnie, $w$ jednym zaledwie akapicie, i szybciutko przeszła do innych tematów ${ }^{106}$, to przekaz Krótkiego opisania i żywotu Teresy Barbary kipi skandalicznością, a nawet pikanterią tych wydarzeń, co ujawnia gwałtowny konflikt i wzajemną niechęć karmelitanek ${ }^{107}$. „Mała kronika” poczętek oraz żywot Zadzikowej zdradzają też, nie tylko w omówionym fragmencie, niepospolitą osobowość autorki, Marii Magdaleny od Zbawiciela, jej bystry umysł, niezależność i talent pisarski na miarę najlepszych pamiętnikarzy epoki.

Natalie Zemon-Davis, podsumowując opowiedziane przez nie trzy siedemnastowieczne żywoty kobiet, napisała: „Kiedyś były postaciami z krwi i kości; potem pozostały po nich wspomnienia, portrety, pisma i sztuka"108. Opisane przez nią bohaterki, dzięki wyjątkowym cechom osobowości, które nakazywały im przełamywać uprzedzenia społeczne i dzięki pismu, pozostawiły po sobie wspomnienia, zapiski, świadectwa swojej egzystencji, przetrwały w pamięci ponad czasem. Potoczyste i jędrne w narracji kroniki klasztorne, również pisane przez karmelitanki, w tym także lubelska, pozwalają spojrzeć na przeszłość grupy, wspólnoty jako całości, ale też jako na przestrzeń działania kobiet konkretnych, ambitnych i mających wiele do powiedzenia. W rzeczywistości zakonu klauzurowego „rozgadane” historie karmelitanek wydają się rewersem obowiązującego milczenia zakonnego, przekorą wobec drewienek noszonych w ustach dla jego zachowania czy dzwonków służących do klasztornej komunikacji, które miały zastępować zbędne słowa ${ }^{109}$.

Kroniki lubelskie, istotne pod względem badawczym ze względu na całościowy projekt studiów dotyczycących klasztornego środowiska miasta, są przykładem intensywności życia za murem, gdzie, pomimo zakładanego milczenia, rozbrzmiewały wszystkie ludzkie emocje. Maria Magdalena od Zbawiciela w żywocie Teresy Barbary od Najświętszego Sakramentu niezwykle często pisała o gromkim śmiechu zakonnic, śmiechu na przekór światu, śmiechu, który był wyrazem sprzeciwu i nieposłuszeństwa wobec niego. Jest to jedna z wyjątkowych cech tego tekstu. Także w Krótkim opisaniu fundacji Niepokalanego Poczęcia Najświętszej Marii Panny, wspominając wejście karmelitanek do nowego domu, uznała ona śmiech

106 Kronika klasztoru karmelitanek bosych ...., s. 101.

107 Teresa Barbara wyprowadzając swoje dwie współsiostry z konwentu św. Józefa, zrzuciła odzież i zupełnie naga pod wierzchnim habitem przeszła do nowego domu. Postanowiła demonstracyjnie nie zabierać ze sobą niczego, oprócz jednej rękopiśmiennej książeczki należącej onegdaj do Stobieńskiej. Wcześniej pomiędzy przeznaczonymi do nowego konwentu karmelitankami a siostrami od św. Józefa doszło do gwałtownego konfliktu o ciało Stobieńskiej (zm. 1649) oraz o kufry z ich rzeczami osobistymi. Zob. Żywot matki Barbary od Najświętszego Sakramentu..., s. 95-97, 103-105.

108 N. Zemon-Davis, Kobiety na marginesach. Trzy siedemnastowieczne życiorysy, przekł. B. Hlebowicz, Wydawnictwo Naukowe PWN, Warszawa 2012, s. 220.

109 Zob. Cz. Gil, Życie codzienne karmelitanek bosych..., s. 112-115. 
za najlepszy sposób ukazania intensywności ich życia. Dlatego tym fragmentem niepublikowanej kroniczki postanowiłam zakończyć pracę.

Po wyjściu ludzi z klasztoru, z klauzury, zamknęły się one trzy matki w klasztorku swoim, będąc napełnione jakąś niezwyczajną w Bogu wesołością, gdyż i powierzchownie tego pokryć nie mogły, bo jak jedna na drugą pojrzała, srodze się śmiały, i spytała jedna drugiej: „Z czego się W[ielebna]M[atka] śmieje?” Owa jej odpowiedziała: „Z tego, co W[asza] M[iłość]”. To jeszcze więcej przybywało wesołości, a to znak był, że miały ekstraordynaryjną łaskę i wnętrzną kontentacyję, która i powierzchownie nie mogła się zataićc ${ }^{\prime 10}$.

\section{Wykaz karmelitanek bosych wymienionych w rozprawie:}

Agnieszka od Trójcy Świętej, Agnieszka Myszkowska, Lublin;

Angela Aleksandra od św. Teresy, Zofia Myszkowska, Lublin;

Anna Józefa od Pana Jezusa, Rupniewska, Kraków;

Anna od Jezusa, Jadwiga Stobieńska, Lublin;

Beata Kolumba od Jezusa, Agnieszka Drzewicka, Lublin;

Beata od Matki Bożej, Beatrycze Drzewicka, Lublin;

Cecylia Teresa od Ofiarowania Najświętszej Marii Panny, Anna Petronela Zacherlanka, Kraków;

Dorota od Najświętszej Marii Panny, Dorota Decjuszówna, Lublin;

Eufrazja od św. Jacka, Teodora Piaseczyńska, Lublin;

Eufrazja od Zwiastownia Najświętszej Marii Panny, Anna Pajewska, Lublin;

Eufrozyna od Pana Jezusa, Katarzyna Jordanówna, Warszawa;

Febronia od Jezusa, nieznane nazwisko świeckie, Lublin;

Katarzyna od Chrystusa Pana, Felicjanna Tyszkiewiczówna, Wilno;

Magdalena od Krzyża, Magdalena Hipolitówna, Kraków;

Maria Magdalena od Zbawiciela, Anna Żaboklicka, Lublin;

Teresa Barbara od Najświętszego Sakramentu, Teofila z Kretkowskich Zadzikowa, Lublin;

Teresa od Jezusa Maryi, Teresa z Kretkowskich Ligęzina, Lublin;

Teresa od Jezusa, Marianna Marchocka, Warszawa;

Nowicjuszki wydalone z klasztoru: panna Uszyńska, panna Sczawinska, panna

Grochowska.

110 Rkps BKB rkps 255, k. 117. 


\section{Bibliografia}

\section{Archiwalia i rękopisy}

Archiwum Główne Akt Dawnych, Archiwum Publiczne Potockich, Warszawa: Archiwum Publiczne Potockich rkps. 57.

Archiwum Prowincji Karmelitów Bosych, Kraków:

rkps AP 104.

rkps AP 246.

rkps AKBW 22.

Biblioteka Karmelitanek Bosych, Kraków, Archiwum:

Certamina klasztoru Niepokalanego Poczęcia, sygn. 46.

Certamina klasztoru św. Józefa., sygn. 44.

Biblioteka Karmelitanek Bosych, Kraków. Rękopisy:

rkps 164: O zwyczajach naszych i niektóre ceremonije domowe.

rkps 253: Księgi, w których są krótko opisane żywoty.

rkps 255: Księga fundacyj klasztorów karmelitanek bosych Prowincyjej Polskiej Ducha Świętego.

rkps 70: Rozporządzenie dnia albo praktyka codzienna tak dla nowicyj jako też nowoprofes, karmelitankom bosym wypisane.

rkps 167: Sporządzenie dnia dla nowicyj.

rkps 268: Zebranie zwyczajów od WW MM naszych fundatorek i pierwszych matek świątobliwościa sławnych konwentu św. Marcina podane i dotąd chwalebnie zachowane, aby były napotym bez uszczerbku trwajace... spisane roku 1729.

Biblioteka PAU i PAN, Kraków:

rkps 1731 .

rkps 2337 II.

Biblioteka Poznańskiego Towarzystwa Przyjaciół Nauk:

rkps 130

Biblioteka Wyższego Seminarium Diecezjalnego w Lublinie:

rkps 455 ,

rkps 457.

Lwowska Narodowa Naukowa Biblioteka Ukrainy im, W. Stefanyka:

rkps CTI118348: Pragnienia dusze pobożnej.

\section{Źródła drukowane}

Klasztory karmelitanek bosych $w$ Polsce, na Litwie i Rusi. Ich poczatek i tułactwo w czasie rozruchów wojennych w XVII wieku. Rzecz osnuta na kronikach klasztornych. Kraków. Klasztor św. Marcina, wyd. Rafał Kalinowski, druk „Czasu”, Kraków 1904. 
Klasztory karmelitanek bosych $w$ Polsce, na Litwie i Rusi. Ich poczatek i tułactwo w czasie rozruchów wojennych w XVII wieku. Rzecz osnuta na kronikach klasztornych. Warszawa, wyd. Rafał Kalinowski, druk „Czasu”, Kraków 1902.

Klasztory karmelitanek bosych $w$ Polsce, na Litwie i Rusi. Ich poczatek i tułactwo w czasie rozruchów wojennych $w$ XVII wieku. Rzecz osnuta na kronikach klasztornych. Wilno, wyd. Rafał Kalinowski, druk „Czasu”, Kraków 1900.

Klasztory Karmelitanek bosych $w$ Polsce, na Litwie i Rusi: ich początek, rozwój i tułactwo w czasie rozruchów wojennych $w$ XVII wieku: rzecz osnuta na kronikach klasztornych. Lwów - Warszawa, wyd. Rafał Kalinowski, druk „Czasu”, Kraków 1901.

Kronika benedyktynek chełmińskich, wyd. Władysław Szołdrski, „Miesięcznik Diecezji Chełmińskiej" 1937, s. 509-529.

Kronika bernardynek lubelskich 1618-1885, oprac. Anna Szylar, Towarzystwo Naukowe Katolickiego Uniwersytetu Lubelskiego Jana Pawła II, Lublin 2010.

Kronika fundacyjna klasztoru mniszek zakonu kaznodziejskiego na Gródku w Krakowie (1620-1639), wstęp i oprac. Anna Markiewicz, Wydawnictwo Esprit S.C., Kraków 2007.

Kronika klasztorna sióstr norbertanek w Imbramowicach 1703-1741, wyd. Włodzimierz Bielak, Waldemar Żurek, Wydawnictwo Jedność, Kielce 2016.

Kronika klasztoru karmelitanek bosych pw. św. Józefa w Lublinie, oprac. Czesław Gil, Wydawnictwo Flos Carmeli, Poznań 2012.

Kronika klasztoru karmelitów bosych $w$ Warszawie, wstęp, przekł., oprac. Czesław Gil, „Karmelitańskie Studia i Materiały Historyczne” 2009, t. 2, s. 143-377.

Kronika pierwsza (metryka), wyd. Małgorzata Borkowska, w: Karol Górski, Małgorzata Borkowska, Historiografia zakonna a wzorce świętości w XVII wieku, Akademia Teologii Katolickiej, Warszawa 1984, s. 278-360.

Kronika poznańskich Karmelitów Bosych, oprac. Piotr Neumann, Wydawnictwo Miejskie, Poznań 2001.

Metryka brygidek lubelskich, oprac. Jarosław Rom Kronika fundacyjna klasztoru mniszek an Marczewski, Wydawnictwo Katolickiego Uniwersytetu Lubelskiego Jana Pawła II, Lublin 2011.

Reguła i konstytucyje zakonnic karmelitanek bosych Zakonu Naświętszej Panny Maryjej $z$ Góry Karmelu, $z$ włoskiego na polski przetłumaczone, druk Andrzej Piotrkowczyk, Kraków 1635.

Żywot matki Barbary od Najświętszego Sakramentu (Zadzikowej), karmelitanki bosej 1609-1670, oprac. Czesław Gil, Wydawnictwo Karmelitów Bosych, Kraków 2013.

\section{Opracowania}

Borek Piotr., Funkcje listów w barokowych diariuszach i pamiętnikach, w: Epistolografia $w$ dawnej Rzeczypospolitej, t. 1. Stulecie XV-XVII), red. Piotr Borek, Marceli Olma, Kraków 2011, s. 279-294. 
Borek Piotr, O polskim pamiętnikarstwie doby baroku, w: $Z$ dziejów staropolskiego pamiętnikarstwa. Przekroje i zbliżenia, red. Piotr Borek, Collegium Columbinum, Kraków 2012, s. 31-52.

Borkowska Małgorzata, Leksykon zakonnic polskich epoki przedrozbiorowej, Wydawnictwo DIG, Warszawa 2005.

Borkowska Małgorzata, Panny siostry w świecie sarmackim, Wydawnictwo Naukowe PWN, Warszawa 2002.

Borkowska Małgorzata, Życie codzienne polskich klasztorów żeńskich w XVII-XVIII wieku, Państwowy Instytut Wydawniczy, Warszawa 1996.

Darnton Robert, Wielka masakra kotów i inne epizody francuskiej historii kulturowej, przekł. Dorota Guzowska, Wydawnictwo Naukowe PWN, Warszawa 2012.

Gil Czesław, Słownik polskich karmelitanek bosych 1612-1914, Wydawnictwo Karmelitów Bosych, Kraków 1999.

Gil Czesław, Życie codzienne karmelitanek bosych w Polsce w XVII i XVIII wieku, Wydawnictwo OO. Karmelitów Bosych, Kraków 1997.

Gwioździk Jolanta, Kultura pisma i książki w żeńskich klasztorach dawnej Rzeczypospolitej XVI-XVIII wieku, Wydawnictwo Uniwersytetu Śląskiego, Katowice 2015.

Gwioździk Jolanta, Piśmiennictwo pragmatyczne w klasztorach żeńskich w XVII-XVIII wieku: zarys problematyki, w: Piśmiennictwo pragmatyczne w Polsce do końca XVIII wieku na tle powszechnym, red. Jan Gancewski, Andrzej Wałkowski, Pracownia Wydawnicza EISet, Olsztyn 2006, s. 43-59.

Krzywy Roman, Funkcje komunikacyjne staropolskiego pamiętnika. Na przykładzie zapisków moskiewskich Stanisława Niemojewskiego, w: Z dziejów staropolskiego pamiętnikarstwa. Przekroje i zbliżenia, red. Piotr Borek, Collegium Columbinum, Kraków 2012, s. 125-140.

Nowicka-Struska Anna, „Strzaly serdeczne z Pisma świętego i ojców świętych zrobione, a od dusze nabożnej ku niebu wypuszczone”. Siedemnastowieczna adaptacja „Pia desideria" Hermana Hugona z rękopisu lubelskich karmelitanek bosych klasztoru Niepokalanego Poczęcia Najświętszej Marii Panny, „Terminus” 2016, t. 18, nr 2(39), s. 131-159.

Nowicka-Struska Anna, Dom i świat. Prywatność domu klasztornego w świetle kroniki karmelitanek bosych klasztoru św. Józefa w Lublinie i tekstów regulujących ich życie $w$ Karmelu, w: Sarmackie theatrum, t. 7, $W$ kręgu rodziny i prywatności, red. Mariola Jarczykowa, Renata Ryba, Wydawnictwo Uniwersytetu Śląskiego, Katowice 2014, s. 187-208.

Nowicka-Struska Anna, Duchowość i piśmiennictwo karmelitańskie w Polsce XVII i XVIII wieku, w: Drogi duchowe katolicyzmu polskiego XVII wieku. Kultura Pierwszej Rzeczypospolitej $w$ dialogu $z$ Europą. Hermeneutyka wartości, t. 7, red. Alina Nowicka-Jeżowa, Wydawnictwo Uniwersytetu Warszawskiego, Warszawa 2016, s. 344-393. 
Nowicka-Struska Anna, Listy w kregu kulturowym karmelitanek bosych w XVII i XVIII wieku. Ze studiów nad rękopisami z Biblioteki Karmelitanek Bosych, w: Epistolografia w dawnej Rzeczypospolitej, t. 5: Stulecia XVI-XIX. Nowa perspektywa historycznoliteracka, red. Marceli Olma, Piotr Borek, Collegium Columbinum, Kraków 2015, s. 193-214.

Nowicka-Struska Anna, Opowieści szeptane. O bliskości kobiet na podstawie żywotopisarstwa lubelskich karmelitanek bosych, w: Sława $z$ dowcipu sama wiecznie stoi... Prace ofiarowane Pani Profesor Alinie Nowickiej-Jeżowej z okazji pięćdziesięciolecia pracy naukowej, red. Mirosława Hanusiewicz-Lavallee, Wiesław Pawlak, Lublin 2018, s. 213-229.

Partyka Joanna, Żona wyćwiczona. Kobieta piszaca w kulturze XVI i XVII wieku, Wydawnictwo IBL PAN, Warszawa 2004.

Pavlouskaya Hanna Grodzieńskie kroniki klasztorne XVII i XVIII wieku. Formy gatunkowe $i$ aspekty komunikacyjne, https://depotuw.ceon.pl/bitstream/handle/ item/400/PAULOUSKAYA\%20DOKTORAT.pdf?sequence=1; [dostęp: 12.05 2018].

Pawłowska Hanna., Zainteresowanie życiem publicznym w kronikach grodzieńskich $z$ XVII-XVIII wieku - zarys problematyki, „Barok” 2011, nr 1, s. 83-93.

Popławska Halina, Kultura literacka karmelitanek bosych (XVII-XVIII wiek), Wydawnictwo Uniwersytetu Gdańskiego, Gdańsk 2006.

Przyklenk Joanna, Staropolska kronika jako gatunek mowy, Wydawnictwo Uniwersytetu Śląskiego Katowice 2009.

Roszak Stanisław, Archiwa sarmackiej pamięci. Funkcje i znaczenia rękopiśmiennych ksiag silva rerum $w$ kulturze Rzeczpospolitej XVIII wieku, Wydawnictwo Uniwersytetu Mikołaja Kopernika Toruń 2004.

Roszak Stanisław, Egodokumenty epoki nowożytnej w perspektywie europejskiej, w: Z dziejów staropolskiego pamiętnikarstwa. Przekroje i zbliżenia, red. Piotr Borek, Collegium Columbinum, Kraków 2012, s. 15-30.

Targosz Karolina, Piórem zakonnicy. Kronikarki w Polsce XVII wieku o swoich zakonach i swoich czasach, Wydawnictwo „Czuwajmy”, Kraków 2002.

Wanat Józef Benignus., Zakon Karmelitów Bosych w Polsce. Klasztory karmelitów i karmelitanek bosych 1605-1975, Wydawnictwo OO. Karmelitów Bosych, Kraków 1979.

Zemon-Davis Natalie, Kobiety na marginesach. Trzy siedemnastowieczne życiorysy, przekł. Bartosz Hlebowicz, Wydawnictwo Naukowe PWN, Warszawa 2012. 


\title{
Za murami klasztoru. Historiografia lubelskich karmelitanek bosych
}

\author{
Streszczenie
}

Badanie piśmiennictwa zakonnic $\mathrm{w}$ jednorodnej przestrzeni miasta służy przywracaniu pamięci o kilku pokoleniach kobiet, które żyły w Lublinie, odkrywaniu ich aktywności intelektualnej, kultury literackiej, obyczajów i zainteresowań, kształtowania obrazu świata. Piśmiennictwo kobiet w epoce staropolskiej wciąż otwiera nowe możliwości poznawcze dla literaturoznawców, badaczy zajmujących się geopoetyką, zainteresowanych zagadnieniami pamięci zbiorowej, prywatności, obiegu teksów, tożsamości bohaterek i identyfikacji zbiorowej czy mentalności grupy. Pozostałe po karmelitankach egodokumenty są dobrym materiałem oglądu naukowego tej wyizolowanej grupy, a mikroskala badawcza pozostaje w obrębie antropologicznej orientacji historycznej. Lubelskie rękopisy, dokumenty i świadectwa aktywności intelektualnej sióstr uległy w XIX wieku całkowitemu rozproszeniu. Artykuł ten ma na celu scalenie wiedzy na temat odnalezionych tekstów karmelitanek lubelskich, określenia najważniejszych cech części dorobku zakonnic, wskazania autorek tekstów, Analizie poddano grupę pism „urzędowych”, (księga wizytacji klasztoru, listy - certaminy) oraz kroniki dwóch lubelskich klasztorów, z których pierwsza, klasztoru pw. Św. Józefa jest znacznych rozmiarów, druga, z kalsztoru pw. Niepokalanego Poczęcia, stanowi zaledwie wstępną część zaginionego najprawdopodobniej tekstu.. Wskazane zostały także inne formy piśmiennictwa klasztornego: żywoty, sylwiczne zbiory duchowościowe, modlitewniki osobiste, zbiór listów, adaptacje zbiorów emblematycznych. Najważniejszymi źródłami wiedzy o lubelskich karmelitankach były kroniki Były one rodzajem domowej historiografii i miały charakter pośredni pomiędzy księgami zmarłych czy księgami obłóczyn, a regularnie prowadzoną narracją, przedstawiającą w porządku chronologicznym wydarzenia z życia grupy. Kronika pierwszego klasztoru obejmuje okres od 1624 do 1701 roku. Księga pisana była konsekwentnie przez kilka anonimowych kronikarek różniących się zainteresowaniami, sposobami precyzowania przekazu i umiejętnościami pisarskimi. Najprawdopodobniej pierwszą autorką kroniki (od 1625 roku) była Febronia od Jezusa. Naturalny przekaz ustny, oprócz osobistego doświadczenia piszącej był najważniejszym źródłem wiedzy o wydarzeniach w domu klasztornym. Ze względu na przyszłego odbiorcę kroniki i potrzebę uwiarygodnienia historiograficznego zostały dodane listy. W strukturze kroniki zostały zamieszczone także inne teksty i gatunki egzogenne. Szczególna uwagę zwracają jednowątkowe mikronarracje. Fragmenty te stanowią o nadzwy- 


\section{Anna Nowicka-Struska}

czajnej wartości literackiej kronik karmelitańskich. Ukazują ekspresję piszących kobiet, umiejętność w zakresie prowadzenia potoczystej narracji i transponowania przekazu oralnego na karty kroniki. Gawędowy ton zapisków kieruje uwage w stronę pamiętnikarskich cech kroniki, a kulturoznawców ku kategorii prywatności, tożsamości i pamięci tej niewielkiej grupy odizolowanych w znacznym stopniu od świata kobiet. Kronikarki wielokrotnie sygnalizowały, jak istotną wartością jest dla konwentu tożsamość grupy. Konfrontacje my - oni, wewnątrz - zewnątrz (klasztoru), podkreślanie indywidualizmu i odmienności zakonu pokazują daleko idącą autoświadomość autorek. Potoczyste w narracji kroniki klasztorne, pozwalają spojrzeć na przeszłość grupy, wspólnoty jako na całość, ale też jako na przestrzeń działania konkretnych, ambitnych i mających wiele do powiedzenia kobiet. W rzeczywistości zakonu klauzurowego „rozgadane” historie karmelitanek wydają się rewersem obowiązującego milczenia zakonnego, przekorą wobec drewienek noszonych w ustach dla jego zachowania czy dzwonków służących do klasztornej komunikacji, które miały zastępować zbędne i uznane za grzeszne słowa.

Słowa kluczowe: historiografia; zakony; literatura; barok; mentalność; kobiety; egodokument; tożsamość, Lublin; miasto; karmelitanki bose; kronika; rękopisy; duchowość; klasztory

\section{Behind Convent Walls. Historiography of Lublin Discalced Carmelite Nuns}

Summary

The research on the written works of nuns in homogeneous city space allows to restore the memory of a few generations of women who lived in Lublin, discover their intellectual activity, their literary culture, customs, interests, and their word view. The ego-documents left by the Carmelite Nuns are good materials for the scientific prospect of this isolated group of women and the research microscale remains in the circle of anthropological historical orientation. The Lublin manuscripts, documents and the evidence of intellectual activity of the nuns were completely dispersed in the $19^{\text {th }}$ century. The aim of the article is to merge the knowledge about the discovered texts of Lublin Carmelite Nuns, determine the main features of the texts and name their authors. In my work I have examined a group of "official" papers (a convent visitation book, letters - certamen) and the chronicles of two Lublin monasteries. The first chronicle of the St. Joseph's Monastery is vast, while the second one from the Immaculate Conception Monastery 
is only an introductive part of the lost text. The article also enumerates other types of convent writing, such as silva rerum spiritual texts, personal prayer books, the compilation of letters, the adaptations of emblematic collections. The main source of information on Lublin Carmelite Sisters were chronicles. The chronicles were a type of domestic historiography, joining the form of the books of the dead or the vesture books, and a narrative presenting the events from nuns' lives in chronological order. The chronicle of the first monastery was written from the year 1624 to 1701 . The book was written consistently by a few anonymous nuns who differed from each other in terms of their interests, writing skills and ways of outlining the information. The first author of the chronicle (from 1625) was presumably sister Febronia of Jesus. Natural oral tradition, a part from personal experience of the author was the most important source of knowledge about the monastic life. In view of a future reader and in order to make the text historiographical and reliable the authors added letters. The chronicle contains also other texts and exogenic genres. Worth mentioning are one-plot micro narrations which highlight extraordinary literary value of the Carmelites' chronicles. The micro narrations show the expression of female authors, their ability to present vibrant and fluent narration, and to transfer oral tradition into the chronicle. A tale character of the notes points to the diary features of the text and guides culture researchers to a category of privacy, identity and memory of a small group of women to a significant degree isolated from the outside world. The chroniclers frequently indicated how crucial for the convent was the identity of a group. The opposition "we - they", "inside - outside (the monastery)", emphasizing individualism and otherness of the convent, show the far-reaching self-consciousness of the authors.

Keywords: historiography; convents; literature; Baroque; mentality; women; ego-documents; identity; Lublin; city; Discalced Carmelite Nuns; chronicle; manuscripts; spirituality; monasteries

Dr hab. Anna Nowica-Struska - adiunkt w Zakładzie Badań Teatralnych i Literatury Staropolskiej Instytutu Filologii Polskiej Uniwersytetu Marii Curie-Skłodowskiej w Lublinie zainteresowania badawcze: kultura literacka Lublina, literatura okolicznościowa, kaznodziejstwo XVII wieku, kultura zakonów w epoce staropolskiej, karmelitanki bose; edytorstwo, rękopisy zakonne. Wydała min.: Andrzej Kochanowski, Kazanie lubelskie, Lubelska Biblioteka Staropolska, t. VIII, Wydawnictwo UMCS, Lublin 2010; Paweł Ruszel, Fawor niebieski, Lubelska Biblioteka Staropolska, t. X, Wydawnictwo UMCS, Lublin 2014; "Strzaty serdeczne z Pisma świętego i ojców świętych zrobione, a od dusze nabożnej ku niebu wypuszczone”. Siedemnastowieczna adaptacja „Pia desideria” Hermana Hugona z rękopisu lubelskich karmelitanek bosych klasztoru Niepokalanego Poczęcia Najświętszej Marii 


\section{Anna Nowicka-Struska}

Panny, „Terminus” 2016, t. 18, nr 2(39), s. 131-159. Opowieści szeptane. O bliskości kobiet na podstawie żywotopisarstwa lubelskich karmelitanek bosych, w: Sława $z$ dowcipu sama wiecznie stoi... Prace ofiarowane Pani Profesor Alinie Nowickiej-Jeżowej z okazji pięćdziesięciolecia pracy naukowej, red. M. Hanusiewicz-Lavallee, W. Pawlak, Wydawnictwo KUL, s. 213-229: Lublin 2018; Nieznany cykl Emblematy na obraz dziada z rękopisu karmelitańskiego Bonawentury od św. Stanisława, Frezera, w: Inwencja i inspiracja w kulturze wczesnonowożytnej, red. M. Pieczyński, B. Niebelska-Rajca, Wydawnictwa IBL PAN, Warszawa 2018, s. 252-267. 